\title{
Innowacyjne inhibitory korozji do strumieni węglowodorowych w kopalniach ropy naftowej i w rafineriach
}

\section{Innovative corrosion inhibitors for hydrocarbon streams in oilfields and refineries}

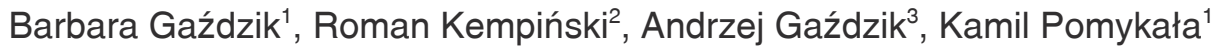 \\ ${ }^{1}$ Instytut Nafty i Gazu - Państwowy Instytut Badawczy \\ ${ }^{2}$ Pachemtech Sp. z.o.o.
}

${ }^{3}$ ArcellorMittal Poland S.A.

\begin{abstract}
STRESZCZENIE: Korozja instalacji podczas procesu wydobycia i przeróbki ropy naftowej stwarza ogromny problem techniczny i ekonomiczny, dlatego stosowane są różne metody ochrony przed korozją, w tym wykorzystywanie inhibitorów korozji. W publikacji opisano przyczyny powstawania korozji oraz przemysłowe metody jej zapobiegania w kopalniach i rafineriach. Przedstawiono metody badań oraz wyniki badań laboratoryjnych inhibitorów korozji opracowanych w ramach projektu: Innowacyjne środki chemiczne z udziatem zmodyfikowanej imidazoliny dla przemystu rafineryjnego, wydobywczego ropy naftowej, hutniczego i maszynowego, dofinansowanego ze środków Narodowego Centrum Badań i Rozwoju. Badania korozyjne wykonane według NACE 1D182 wykazały, że przy dozowaniu do mieszanki ropa-woda $25 \mathrm{mg} /$ litr inhibitora korozji do dozowania ciągłego do odwiertów i ropociągów Pachem-CWR-1011 szybkość korozji płytek Steel Shimstock obniżyła się z wartości około 1,4 mm/rok do poniżej 0,05 mm/rok, poziom ochrony przed korozją wynosił 96,7\%, a rozdział ropy od wody nastąpił w czasie do 15 minut. Badania skłonności do emulgowania według ASTM G 170-06, z udziałem tego inhibitora w ilości $50 \mathrm{mg} /$ litr, wykazały, że do 15 minut zaobserwowano ostry rozdział ropy naftowej od wody. Badania, według NACE 1D182, inhibitora korozji do dozowania okresowego do odwiertów i ropociągów Pachem-CWR-1021 wykazały, że przy jego dozowaniu w I etapie - w celu wytworzenia powłoki ochronnej - w ilości $9000 \mathrm{mg} /$ litr mieszanki ropa-woda szybkość korozji płytek Steel Shimstock w II etapie obniżyła się do poniżej $0,05 \mathrm{~mm} / \mathrm{rok}$, a stopień ochrony przed korozją wynosił 98,60\%. Po badaniu do 15 minut zaobserwowano wyraźny rozdział ropy naftowej od wody. Badania grubości warstwy wykazały, że Pachem-CWR-1021 tworzy powłokę ochronną o grubości około 20 mikrometrów. Przeprowadzono badania inhibitora Pachem-CR-1012 do dozowania w sposób ciągły do rur oparowych i orosień kolumn destylacyjnych w celu ochrony przed korozją kolumn destylacyjnych, układów kondensacyjnych i rurociągów na instalacji destylacji rurowo-wieżowej DRW. Badania według NACE 1D182 wykazały, że inhibitor przy dozowaniu $15 \mathrm{mg} /$ litr benzyny ogranicza szybkość korozji z poziomu około $2 \mathrm{~mm} /$ rok do poniżej $0,01 \mathrm{~mm} / \mathrm{rok}$, a stopień ochrony przed korozją wynosi 99,8\%. Inhibitor znakomicie przeciwdziała tworzeniu się emulsji - po badaniu uzyskano niezawodnioną, pozbawioną produktów korozji benzynę surową i czystą, pozbawioną węglowodorów wodę kondensacyjną.
\end{abstract}

Słowa kluczowe: ropa naftowa, kopalnia, rafineria, inhibitor, korozja.

ABSTRACT: Corrosion of installations during the process of oil production and processing creates a huge technical and economic problem, which is why various methods of corrosion protection are applied, including the use of corrosion inhibitors. The paper describes the causes of corrosion and industrial methods of its prevention in oilfields and refineries. The research methods and laboratory test results of corrosion inhibitors developed as part of the Project: Innovative chemicals with modified imidazoline for the refinery, oilfields, metallurgy and machinery industries, co-financed by the National Center for Research and Development. Corrosion tests (NACE 1D182) have shown that dosing the Pachem-CWR-1011 corrosion inhibitor for continuous injection to wells and pipelines to an oil/water mixture at $25 \mathrm{mg} /$ liter, decreased the corrosion rate of Steel Shimstock plates from ca $1.4 \mathrm{~mm} /$ year to below $0.05 \mathrm{~mm} / \mathrm{year}$, and corrosion protection was 96.7\%. Emulsification tendency evaluation (ASTM G 170-06) showed a sharp separation of crude oil and water phases within up to 15 minutes when $50 \mathrm{mg} /$ liter of this inhibitor was used. Tests of the Pachem-CWR-1021 corrosion inhibitor for periodical injection to wells and pipelines showed that the rate of corrosion of Steel Shimstock plates, in the second stage, decreased to a level below $0.05 \mathrm{~mm} / \mathrm{year}$, and the degree of corrosion protection was $98.60 \%$ when a treat rate of $9,000 \mathrm{mg} /$ liter of oil-water mixture was used in the first stage to produce a protective coating. After the tests, a clear separation of oil and water was observed within up to 15 minutes. The film layer thickness measurements showed that Pachem-CWR-1021 forms a protective film with a thickness of about

Autor do korespondencji: B. Gaździk, e-mail: barbara.gazdzik@inig.pl

Artykuł nadesłano do Redakcji 28.09.2018 r. Zatwierdzono do druku 16.05.2019 r. 
20 micrometers. Corrosion inhibitor Pachem-CR-1012 for continuous dosing into the vapor pipes and refractory distillation columns to protect against corrosion of the installation on the CDU plant was also tested. The NACE 1D182 tests have shown that the inhibitor, dosed at the rate of $15 \mathrm{mg} /$ liter of gasoline reduces the corrosion rate from $2 \mathrm{~mm} /$ year to below $0.01 \mathrm{~mm} /$ year, and the degree of corrosion protection is $99.8 \%$. The inhibitor is excellent in protecting against the formation of emulsions - after the test, a non-watery crude oil free corrosion products and clear condensation water free of hydrocarbons were obtained.

Key words: crude oil, oil well, refinery, inhibitor, corrosion.

\section{Wprowadzenie}

Instytut Nafty i Gazu - Państwowy Instytut Badawczy we współpracy z firmą Pachemtech Sp. z o.o. zrealizował projekt: Innowacyjne środki chemiczne z udziałem zmodyfikowanej imidazoliny dla przemystu rafineryjnego, wydobywczego ropy naftowej, hutniczego i maszynowego, dofinansowany ze środków Narodowego Centrum Badań i Rozwoju, w ramach Programu Badań Stosowanych, Ścieżka A.

$\mathrm{W}$ ramach projektu zostały $\mathrm{m}$.in. opracowane technologie innowacyjnych inhibitorów korozji do ochrony przed korozją instalacji wydobywczych w kopalniach ropy naftowej, w tym do dozowania ciągłego Pachem-CWR-1011 i do dozowania okresowego Pachem-CWR-1021, oraz do ochrony przed korozją instalacji destylacji rurowo-wieżowej DRW w rafineriach Pachem-CR-1012.

\section{Korozja w kopalniach ropy naftowej i jej skutki}

Korozja jest to niszczenie materiałów pod wpływem chemicznej lub elektrochemicznej reakcji z otaczającym środowiskiem oraz w wyniku działania mikroorganizmów. W kopalniach ropy korozji ulegają rury wydobywcze, rury okładzinowe, pompy wgłębne żerdziowe, rurociągi tłoczące ropę naftową ze złoża do kopalni, zbiorniki. Wyżej wymienione instalacje wykonane są ze stali węglowej lub stopowej. Szczególnie niską odporność na korozję wykazuje stal węglowa. Postęp korozji mierzony jest głównie poprzez ocenę jej szybkości. Szybkość korozji jest uzależniona od szeregu czynników, w tym od przeciążenia materiałów, wynikającego z turbulentnego przepływu wielofazowych układów wodno-ropno-gazowych, temperatury i ciśnienia (Manning i Thompson, 1995; Wojnar, 1997; Fink, 2003; Baszkiewicz i Kamiński, 2006; Stachowicz, 2009, 2010).

Eksploatowanej ropie naftowej zawsze towarzyszy woda produkcyjna. Zawiera ona sole nieorganiczne, w tym chlorki i siarczany sodu, potasu, wapnia, magnezu oraz węglany wapnia i magnezu. W roztworach zawierających sole zachodzą procesy korozji elektrochemicznej, spowodowane działaniem ogniw galwanicznych tworzących się między spasywowaną powierzchnią metalu a powierzchnią, która tej warstewki nie posiada (Moiseeva i Kuznetsov, 1997; Wang et al., 2001; Baszkiewicz i Kamiński, 2006).

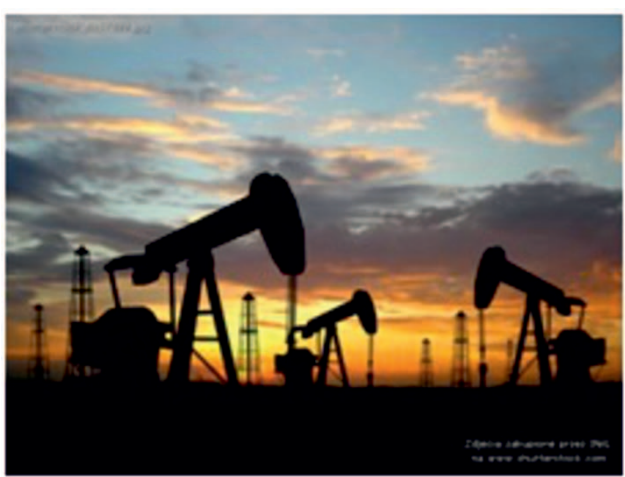

Fot. 1. Kiwon pompowy

Photo 1. Crude oil Pumpjack

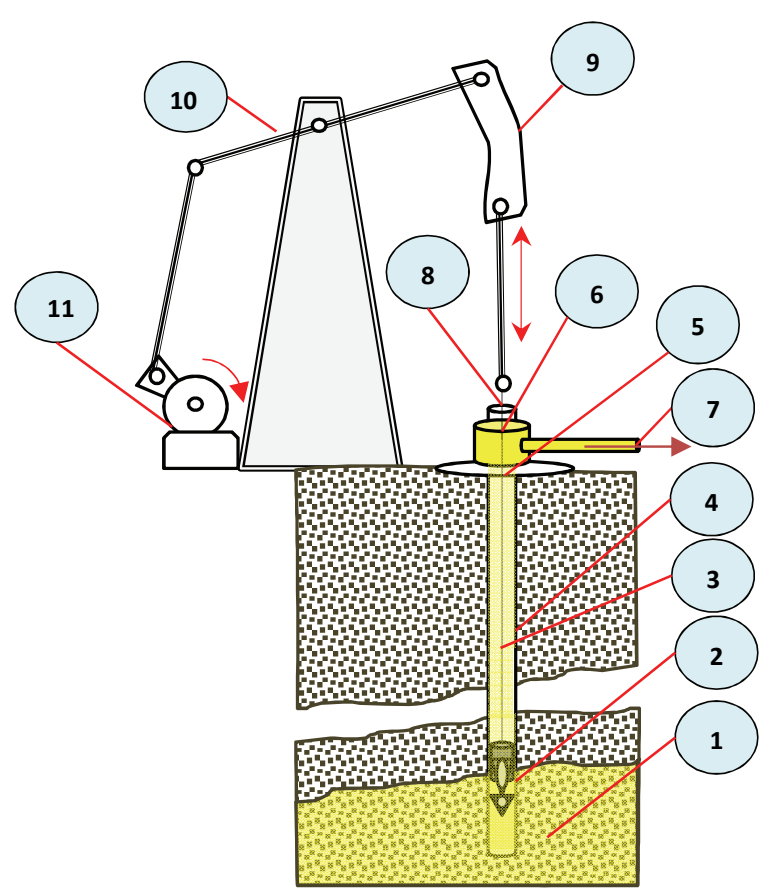

Legenda:

1. Złoże roponośne

2. Pompa z zespołem zaworów zwrotnych

3. Żerdź pompowa

4. Obudowa szybu (rury okładzinowe i rury wydobywcze)

5. Betonowy fundament

6. Głowica szybu

7. Odprowadzenie urobku

8. Drążek prowadzący

9. Głowica kiwona

10. Zespół ramion napędu

11. Silnik z kołem napędowym i przeciwwagą

Rys. 1. Schemat kiwona pompowego (autor: A. Gaździk)

Fig. 1. Pumpjack diagram (author: A. Gaździk) 


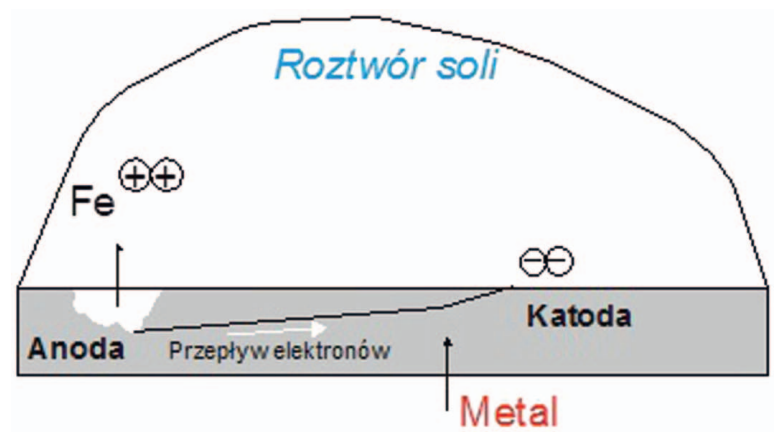

Rys. 2. Korozja elektrochemiczna (autor: A. Gaździk)

Fig. 2. Electrochemical corrosion (author: A. Gaździk)

Ropa naftowa często zawiera nawet kilka procent siarkowodoru, chociaż znane są również takie, które zawierają kilkanaście procent tego związku. Siarkowodór rozpuszcza się w wodzie złożowej, obniżając jej pH i powodując bardzo agresywną korozję. W wyniku reakcji siarkowodoru z żelazem powstaje siarczek żelaza FeS oraz wodór $\mathrm{H}_{2}$. Siarczek żelaza pasywuje powierzchnię metalu i w pierwszej fazie chroni przed korozją, lecz nawet niewielkie uszkodzenie tej powłoki prowadzi do intensyfikacji korozji. Skutkiem korozji jest powstawanie wżerów, a część wydzielonego wodoru wnika do stali i staje się przyczyną pęcherzenia stali i kruchości wodorowej.

$$
\mathrm{Fe}^{0}+\mathrm{H}_{2} \mathrm{~S} \rightarrow \mathrm{FeS}+\mathrm{H}_{2}
$$

Duże zniszczenia korozyjne są spowodowane obecnością ditlenku węgla podczas wydobycia ropy naftowej. Ditlenek węgla, rozpuszczając się w wodzie, tworzy kwas węglowy $\mathrm{H}_{2} \mathrm{CO}_{3}$, który reaguje z żelazem, tworząc węglan żelaza $\mathrm{FeCO}_{3}$, powstaje przy tym również wodór. Charakterystyczną cechą korozji wynikającej z obecności ditlenku węgla jest obecność wygładzonych krawędzi instalacji (Stachowicz, 2010, 2013).

$$
\begin{gathered}
\mathrm{CO}_{2}+\mathrm{H}_{2} \mathrm{O} \rightarrow \mathrm{H}_{2} \mathrm{CO}_{3} \\
\mathrm{H}_{2} \mathrm{CO}_{3}+\mathrm{Fe}^{0} \rightarrow \mathrm{FeCO}_{3}+\mathrm{H}_{2}
\end{gathered}
$$

Korozja biologiczna MIC (ang. microbiologically induced corrosion) jest procesem intensyfikowanym działaniem bakterii, a produkty przemian metabolicznych bakterii, takie jak siarkowodór, kwasy organiczne i nieorganiczne, wywołują korozję i wzmagają jej szybkość. W kopalniach ropy procesy korozyjne spowodowane są głównie działaniem bakterii redukujących siarczany (SRB, ang. sulfate-reducing bacteria) z gatunku beztlenowych Desulfovibrio desulfuricans, które namnażają się w warunkach anaerobowych w ropie naftowej. Bakterie te są najbardziej aktywne pod powierzchnią kamienia powstałego na skutek odkładania się osadów nieorganicznych. Bakterie SRB indukują poniższe reakcje (Fink, 2003):

$$
\begin{gathered}
4 \mathrm{Fe}+\mathrm{SO}_{4}{ }^{2-}+4 \mathrm{H}_{2} \mathrm{O}=3 \mathrm{Fe}(\mathrm{OH})_{2}+\mathrm{FeS}+2 \mathrm{OH}^{-} \\
\mathrm{Fe}^{2+}+\mathrm{H}_{2} \mathrm{~S}=\mathrm{FeS}+2 \mathrm{H}^{+}
\end{gathered}
$$

Szybkość korozji w kopalniach ropy zwiększa się wraz $\mathrm{z}$ zawartością tlenu w układzie, jest również uzależniona od temperatury i osiąga maksimum w temperaturze około $70^{\circ} \mathrm{C}$.

Skutki procesów korozyjnych w kopalniach to zmniejszenie grubości ścianek rur wydobywczych, okładzinowych i przesyłowych oraz ścian zbiorników, tworzenie się głębokich wżerów, które mogą prowadzić do rozszczelnienia rur, pęcherzenia, pękania i tzw. kruchości wodorowej stali wywołanej działaniem $\mathrm{H}_{2} \mathrm{~S}$ (Moiseeva et al., 1998; Reiss i Toporowski, 2000a, 2000b; Jewulski, 2007; Jewulski i Wojnarowski, 2007; Stachowicz, 2009; Abd El-Lateef et al., 2012; Popoola et al., 2013).

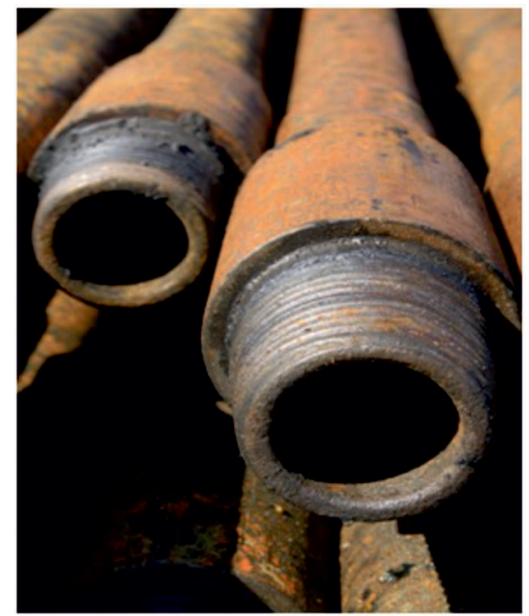

Fot. 2. Rurociągi z widoczną korozją równomierną

Photo 2. Pipelines with visible uniform corrosion

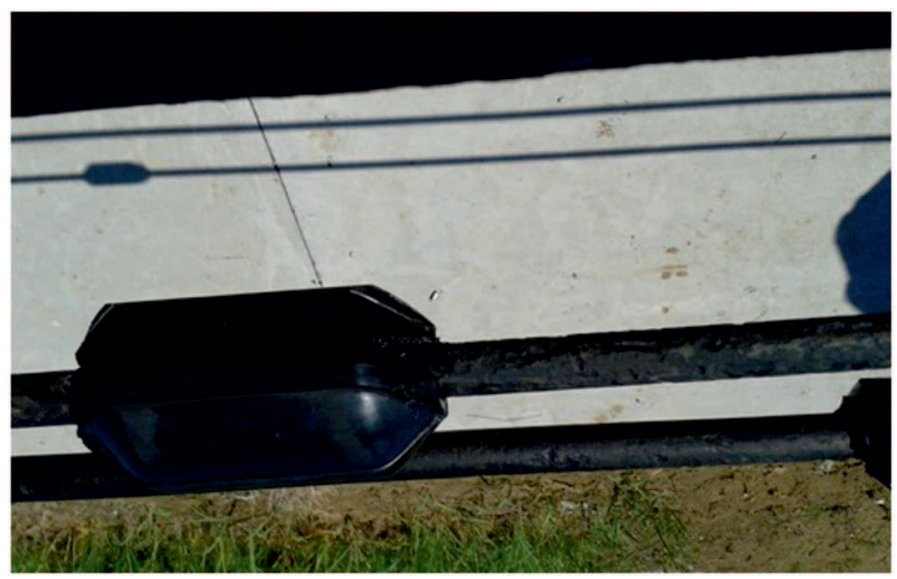

Fot. 3. Element pompy żerdziowej z widocznymi wżerami - skutkiem korozji elektrochemicznej

Photo 3. The rod pump element with visible pits as a result of electrochemical corrosion

\section{Zapobieganie korozji w kopalniach ropy poprzez stosowanie inhibitorów korozji}

Inhibitory korozji wciąż odgrywają kluczową rolę w przeciwdziałaniu skutkom korozji związanej z wydobyciem i transportem ropy naftowej. W kopalniach ropy stosowane 
są inhibitory korozji do dozowania w sposób ciągły, w ilości 10-100 ppm, lub do dozowania w sposób okresowy. Inhibitory korozji stosowane okresowo dozuje się porcjami w ilości 500-5000 ppm lub poprzez recyrkulację rozcieńczonego inhibitora w oleju napędowym lub ropie naftowej, lub poprzez nanoszenie inhibitora na elementy pomp żerdziowych.

Przyjmuje się, że właściwa ochrona przeciwkorozyjna w kopalniach ropy powinna zapewnić spadek szybkości korozji stali do poziomu poniżej 100 mikrometrów/rok, najkorzystniej poniżej 50 mikrometrów/rok.

Inhibitory korozji do dozowania ciągłego są to na ogół inhibitory typu film forming, zawierające składniki tworzące warstwę ochronną o silnych właściwościach przeciwkorozyjnych, która jest uzupełniana w sposób ciągły. Utworzony film ochronny zapobiega korozji, ściśle przylegając do podłoża. Chroni powierzchnie odwiertów i ropociągów przed działaniem chlorków i tlenu, zawartych w wodzie złożowej, oraz siarkowodoru i ditlenku węgla, zawartych w ropie naftowej i gazie ziemnym. Inhibitory korozji do ciągłego dozowania podawane są za pomocą pomp dozujących.

Środki przeciwkorozyjne do dozowania okresowego są specyficznymi inhibitorami, zawierającymi składniki filmotwórcze o właściwościach przeciwkorozyjnych i tworzące trwałą powłokę na powierzchni metalu. Powstała trwała powłoka inhibitora, najczęściej o grubości 20-70 mikrometrów, zapobiega korozji przez długi czas, często nawet kilka miesięcy, nie zmieniając swoich właściwości, ściśle przylegając do podłoża. Środki przeciwkorozyjne stosowane okresowo dozowane są pomiędzy tłoki do czyszczenia ropociągów i rozprowadzane po wewnętrznej powierzchni ropociągu lub zabezpieczają odwierty poprzez recyrkulację. W przypadku żerdziowych tłokowych pomp wgłębnych ich elementy mogą być zabezpieczane poprzez ręczne nanoszenie środka przeciwkorozyjnego za pomocą pędzla lub zanurzenie elementów pompy w środku przeciwkorozyjnym w celu utworzenia warstwy ochronnej, a takie działania można prowadzić podczas przerw remontowych, gdy elementy pompy żerdziowej znajdują się na powierzchni.

Dużym problemem podczas stosowania inhibitorów korozji, zarówno do dozowania ciągłego, jak i okresowego, jest ryzyko utworzenia emulsji ropy naftowej z wodą złożową, często trudnej do rozdzielenia. Powstawaniu emulsji sprzyja turbulentny przepływ ropy naftowej z wodą złożową, pod dużym ciśnieniem. Stabilność emulsji zwiększa się wraz z udziałem w ropie emulgatorów naturalnych, takich jak asfalteny, kwasy naftenowe i żywice, sprzyja jej również obecność małych, skrystalizowanych cząsteczek parafin i glinokrzemianów.

Niewłaściwy dobór inhibitora korozji lub zbyt wysokie jego dozowanie może być przyczyną powstania stabilnej emulsji ropa-woda, a co za tym idzie - wysokiego poziomu chlorków w ropie naftowej, często wielokrotnie przewyższającego poziom wymagany przez odbiorcę, tj. rafinerię. Niestety chlorki magnezu i wapnia zawarte w ropie docierającej do rafinerii są odpowiedzialne za najbardziej intensywną korozję podczas przerobu ropy w rafinerii na instalacji destylacji rurowo-wieżowej. Powoduje to tworzenie się osadów na wymiennikach ciepła oraz intensywną korozję instalacji, szczególnie szczytu kolumny atmosferycznej. Woda złożowa zawierająca duże ilości węglowodorów wykazuje bardzo wysokie chemiczne zapotrzebowanie tlenu, którego poziom często nie mieści się w zakresie wymagań środowiskowych.

Od inhibitorów korozji wymaga się, aby nie tylko nie sprzyjały tworzeniu się emulsji ropa-woda, nie powodowały jej stabilizacji, lecz dodatkowo przyspieszały rozdział ropy od wody. Proces takiego rozdziału powinien być procesem krótkotrwałym, o wysokiej efektywności, a uzyskana ropa naftowa powinna zawierać niewielką ilość chlorków i wody. Od nowoczesnych inhibitorów korozji wymaga się również przeciwdziałania tworzeniu się osadów mineralnych na stalowych elementach instalacji w kopalniach ropy, co zapobiegnie częstej w kopalniach ropy korozji podosadowej (Reiss i Toporowski, 2000c; Fang, 2001; Sintoorahat et al., 2008; Fink, 2011; Menendez et al., 2011; Osokogwu i Oghenekaro, 2012).

\section{Korozja w rafineriach i jej skutki}

Procesy korozyjne w rafineriach występują na instalacjach destylacji ropy naftowej DRW, hydroodsiarczania i reformingu benzyn, fluidalnego krakingu katalitycznego, w wytwórni olefin, w zbiornikach magazynowych i rurociągach oraz w układach wody chłodzącej. Awarie będące skutkiem procesów korozyjnych występują głównie w urządzeniach takich jak: kolumny destylacyjne (szczególnie w szczytowych sekcjach), kondensatory powietrzne, wymienniki, rurociągi oparowe, przegrzewacze pary, zbiorniki, pompy, zawory, kominy i reaktory (Baszkiewicz i Kamiński, 2006; Stachowicz, 2009, 2010).

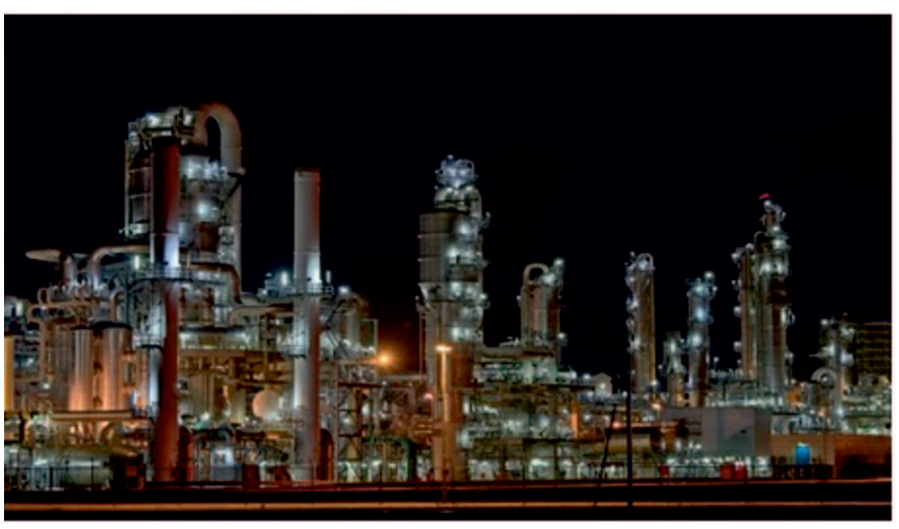

Fot. 4. Instalacja destylacji rurowo-wieżowej (DRW)

Photo 4. Crude Oil Distillation Unit (CDU) 
W rafineriach procesy korozyjne dotyczą głównie instalacji wykonanych ze stali węglowej i stopowej oraz elementów aparatury i urządzeń z mosiądzu.

W instalacjach destylacji rurowo-wieżowej DRW, gdzie surowcem jest ropa naftowa, do głównych czynników korozyjnych należą kwaśne gazy: $\mathrm{H}_{2} \mathrm{~S}_{\text {i CO}}$, kwasy nieorganiczne: $\mathrm{HCl}, \mathrm{H}_{2} \mathrm{SO}_{3}, \mathrm{H}_{2} \mathrm{SO}_{4}, \mathrm{H}_{2} \mathrm{CO}_{3}$ oraz organiczne kwasy naftenowe. Czynnikiem wzmagającym korozję jest wysoka temperatura procesu. Węglowodory zawierające parę wodną, chlorowodór i siarkowodór, opuszczając kolumnę destylacyjną w temperaturze $120-130^{\circ} \mathrm{C}$, są najbardziej korozyjne i wywołują intensywne procesy korozyjne.

Ropy naftowe po wstępnym oczyszczeniu na polu naftowym dostarczane są do rafinerii. Wciąż jednak zawierają wiele zanieczyszczeń pochodzących ze złoża, środków transportu, zbiorników i innych urządzeń, z którymi stykała się ropa na drodze do rafinerii. Należą do nich osady mineralne, produkty korozji, parafiny i asfalteny. Dostarczane do rafinerii ropy naftowe zawierają od $30 \mathrm{do} 1500 \mathrm{mg} / \mathrm{dm}^{3}$ soli nieorganicznych oraz $0,1-1,0 \%(v / v)$ wody. Sole pochodzące $z$ wody morskiej zawierają $70-80 \%(\mathrm{~m} / \mathrm{m}) \mathrm{NaCl}, 10-20 \%(\mathrm{~m} / \mathrm{m}) \mathrm{MgCl}_{2}$ i $10-20 \%(\mathrm{~m} / \mathrm{m}) \mathrm{CaCl}_{2}$.

Za najbardziej intensywną korozję podczas przerobu ropy w rafinerii odpowiedzialne są chlorki magnezu i wapnia, ulegające hydrolizie $\mathrm{z}$ wytworzeniem chlorowodoru $\mathrm{HCl}$ podczas procesu podgrzewania ropy naftowej. Stąd ograniczenia dotyczące zawartości chlorków w ropie poddawanej destylacji w instalacji DRW, która nie powinna przekraczać $10 \mathrm{mg} / \mathrm{dm}^{3}$ ropy. Chlorowodór $\mathrm{HCl}$ powoduje intensywną korozję instalacji DRW, szczególnie szczytowych sekcji kolumn destylacyjnych.

Z kolei w wyniku działania siarkowodoru i ditlenku węgla powstaje wodór atomowy, który przenika do wnętrza struktury krystalicznej metalu (stali, żelaza). Następnie atomy te, łącząc się, tworzą wodór cząsteczkowy, którego gromadzenie się zwiększa ciśnienie wewnętrzne materiału. Stanowi to przyczynę powstawania pęknięć sieci krystalicznej. W wyższych temperaturach $\left(>200^{\circ} \mathrm{C}\right)$ korozja wodorowa może zachodzić w fazie gazowej, czego powodem jest zachodząca reakcja dysocjacji cząsteczki $\mathrm{H}_{2}$. Korozja wodorowa jest przyczyną tzw. kruchości wodorowej, co przejawia się w znacznym spadku plastyczności i pękaniu materiału konstrukcyjnego. Negatywne oddziaływanie wodoru zachodzi najszybciej, gdy odczyn $\mathrm{pH}$ wody produkcyjnej kształtuje się poniżej 4,0.

Procesy korozyjne w rafineriach intensyfikowane są również działaniem beztlenowych bakterii redukujących siarczany (SRB). Niekorzystne działanie powoduje też obecny w gazach rafineryjnych cyjanowodór, który rozpuszcza pasywującą warstwę ochronną utworzoną na powierzchni metalu, zgodnie $\mathrm{z}$ równaniem:

$$
\mathrm{FeS}+2 \mathrm{HCN} \rightarrow \mathrm{Fe}^{2+}+2 \mathrm{CN}^{-}+\mathrm{H}_{2} \mathrm{~S}
$$

W wyniku rozpuszczenia warstwy ochronnej (FeS) z powierzchni stalowych wodór powstały w reakcji żelaza z siarkowodorem i ditlenkiem węgla dyfunduje do wnętrza stalowych materiałów, co w efekcie powoduje pęcherzenie stali i kruchość wodorową.

Skutki procesów korozyjnych w rafinerii to zmniejszenie grubości ścianek instalacji, głębokie wżery, pęcherzenie stali, które jest przyczyną tzw. kruchości wodorowej, korozja międzykrystaliczna, powodująca silny spadek wytrzymałości materiałów konstrukcyjnych, oraz tworzenie się osadów zatykających wymienniki ciepła, wiązki rur, filtry, rurki, zawory i zanieczyszczających rurociągi technologiczne. Pośrednimi skutkami korozji są: konieczność remontów instalacji, pogorszenie jakości destylatów oraz zanieczyszczenie środowiska (Tishkevich et al., 1996; Chen et al., 2000; Kuznetsov i Vagapov, 2000; Papavinasam, 2000; Pawłowska i Olszewska, 2006; Arora i Pandey, 2012; Gaździk, 2016; Groysman, 2016).

\section{Zapobieganie korozji w rafineriach poprzez stosowanie inhibitorów korozji}

Postęp korozji w rafineriach mierzony jest głównie poprzez ocenę jej szybkości. Szybkość korozji zależy od szeregu czynników wymienionych powyżej, lecz również od przeciążenia materiałów, prędkości przepływu węglowodorów oraz wartości temperatury i ciśnienia towarzyszących procesom rafineryjnym. Im temperatura procesu jest wyższa, tym szybkość korozji jest większa. W rafineriach, w których nie stosuje się inhibitorów, szybkość korozji stalowych elementów instalacji może wynosić od jednego do kilku milimetrów na rok, a w przypadku stali węglowych nawet do $10 \mathrm{~mm} /$ rok, w zależności od jakości surowca i warunków pracy. Oprócz pomiaru szybkości korozji w rafineriach oceniane są także: stopień nawodorowania stali, ilość tworzących się osadów oraz obecność wżerów i pęknięć elementów konstrukcyjnych.

W instalacjach DRW przeciwdziała się korozji, dozując, oprócz inhibitora korozji, środki deemulgujące oraz neutralizatory kwaśnych oparów. Inhibitory korozji w instalacjach DRW dozuje się w sposób ciągły do strumieni węglowodorowych, w ilości od 5 do $30 \mathrm{mg} /$ litr benzyny surowej. Przyjmuje się, że właściwa ochrona przeciwkorozyjna powinna zapewnić spadek szybkości korozji stali do poziomu $<0,11-0,25 \mathrm{~mm} / \mathrm{rok}$, poziomu nawodorowania stali do wartości $<0,2 \mathrm{ppm} \mathrm{H}_{2} / \mathrm{m}$-c, a ilości osadów do poziomu $<2,0 \mathrm{~g} / \mathrm{m}^{2}$ na dobę (Pawłowska i Olszewska, 2006). 
Tabela 1. Metody zapobiegania korozji na instalacjach DRW (Pawłowska i Olszewska, 2006)

Table 1. Corrosion prevention methods on CDU

\begin{tabular}{|l|l|l|l|l|}
\hline Środek chemiczny & \multicolumn{1}{|c|}{ Rodzaj procesu } & \multicolumn{1}{|c|}{ Dzialanie } & \multicolumn{1}{c|}{ Miejsce dozowania } & \multicolumn{1}{c|}{ Kontrola procesu } \\
\hline \hline Deemulgator & $\begin{array}{l}\text { odwadnianie i odsala- } \\
\text { nie ropy naftowej }\end{array}$ & $\begin{array}{l}\text { usuwanie chlorków } \mathrm{Ca} \\
\text { i Mg z ropy naftowej }\end{array}$ & $\begin{array}{l}\text { do strumienia surowej ropy } \\
\text { w elektrodehydratorach }\end{array}$ & $\begin{array}{l}\text { ocena zawartości chlorków po } \\
\text { procesie deemulgowania }\end{array}$ \\
\hline $\begin{array}{l}\text { Wodny roztwór } \\
\text { wodorotlenku }\end{array}$ & neutralizacja & $\begin{array}{l}\text { neutralizacja } \mathrm{HCl}, \mathrm{H}_{2} \mathrm{~S}, \mathrm{CO}_{2} \\
\text { i innych kwasów }\end{array}$ & $\begin{array}{l}\text { do strumienia odsolonej } \\
\text { ropy }\end{array}$ & ocena odczynu pH kondensatów \\
\hline Aminy lotne & neutralizacja & $\begin{array}{l}\text { neutralizacja pozostałości } \mathrm{HCl}, \\
\mathrm{H}_{2} \mathrm{~S}, \mathrm{CO}_{2} \text { i innych kwasów }\end{array}$ & $\begin{array}{l}\text { do strumienia oparów } \\
\text { szczytowych kolumny }\end{array}$ & ocena odczynu pH kondensatów \\
\hline $\begin{array}{l}\text { Inhibitory korozji } \\
\text { stali i mosiądzu }\end{array}$ & $\begin{array}{l}\text { działanie przeciwko- } \\
\text { rozyjne }\end{array}$ & $\begin{array}{l}\text { tworzą warstwę ochronną na } \\
\text { powierzchniach metali }\end{array}$ & $\begin{array}{l}\text { do strumienia orosienia } \\
\text { i oparów szczytowych } \\
\text { kolumny }\end{array}$ & $\begin{array}{l}\text { ocena szybkości korozji stali } \\
\text { i mosiądzu; ocena nawodoro- } \\
\text { wania stali oraz ilości osadów }\end{array}$ \\
\hline
\end{tabular}

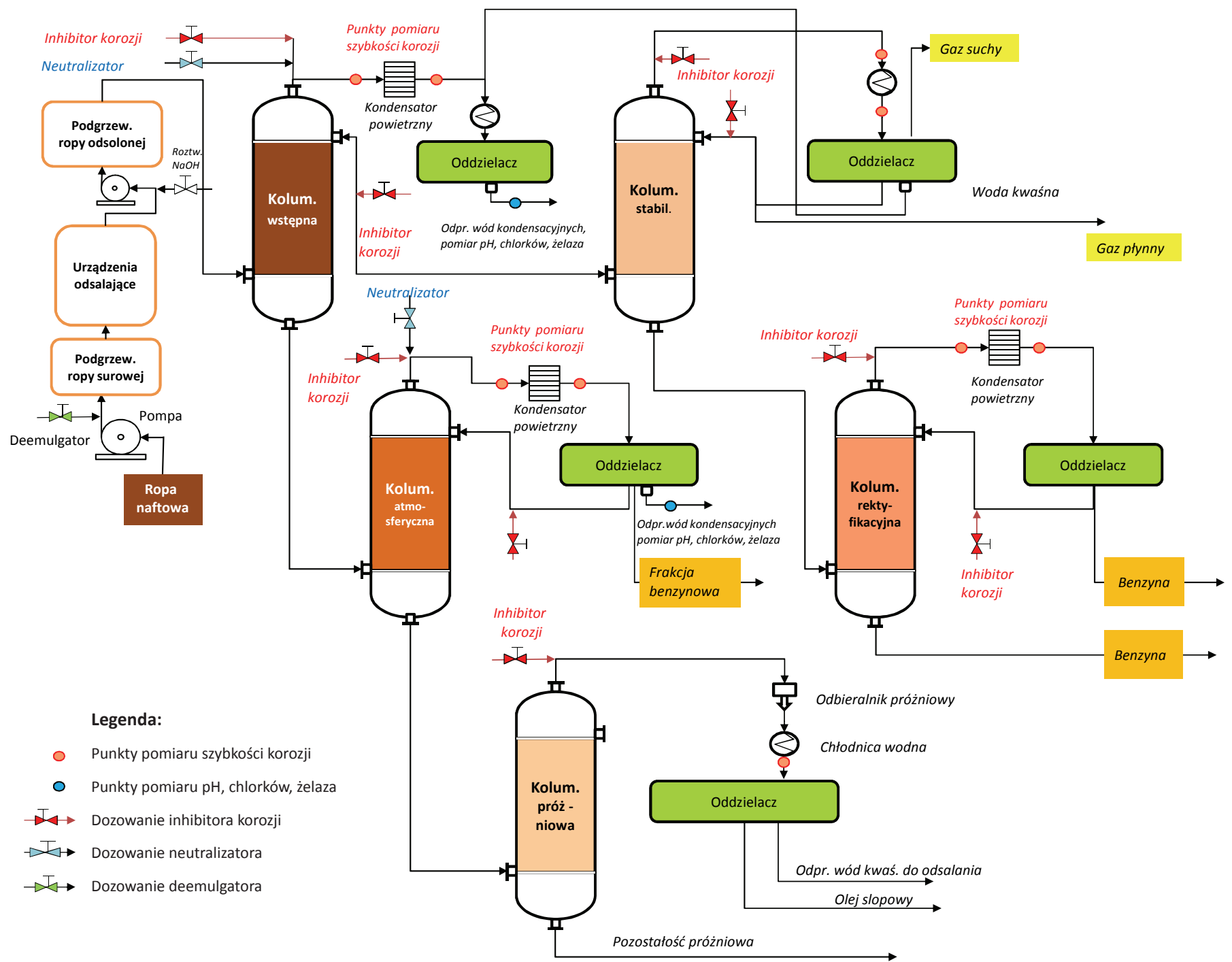

Rys 3. Schemat ideowy ochrony przeciwkorozyjnej i monitoringu korozji instalacji destylacji rurowo-wieżowej (autor: A. Gaździk)

Fig. 3. Schematic diagram of corrosion protection and corrosion monitoring of a pipe and tower distillation installation (author: A. Gaździk)

\section{Część doświadczalna}

W ramach niniejszej pracy poddano badaniom próbki inhibitorów korozji do dozowania ciągłego i okresowego w kopalniach ropy naftowej i do dozowania ciągłego na instalacjach DRW w rafineriach $-o$ właściwościach przedstawionych w tabeli 2 .
Inhibitor korozji Pachem-CWR-1011 - do ciagtego dozowania, do ochrony odwiertów, urzadzeń wydobywczych i rurociągów transportujących rope naftowa w kopalniach ropy naftowej i gazu

Inhibitor korozji Pachem-CWR-1011 jest inhibitorem korozji typu film forming, do dozowania ciągłego w ilości 
10-100 mg/litr ropy i wody. Zawiera składniki tworzące na powierzchni instalacji trwałą powłokę antykorozyjną oraz składniki neutralizujące czynniki korozyjne występujące w ropie naftowej, a składniki te są w sposób ciągły uzupełniane. Utworzony film ochronny chroni przed działaniem siarkowodoru $\mathrm{H}_{2} \mathrm{~S}$, ditlenku węgla $\mathrm{CO}_{2}$ i chlorków, nie dopuszczając do powstawania wżerów oraz zapobiegając korozji równomiernej. Zapewnia maksymalną ochronę przed korozją nawet przy ekstremalnie wysokiej zawartości wody w węglowodorach. Inhibitor rozpuszcza się w wodzie, wykazuje przy tym doskonałe właściwości przeciwdziałania tworzeniu się emulsji ropy naftowej z wodą złożową, a jego zastosowanie powoduje, że rozdział obu faz: ropy naftowej i wody podczas procesu odstawania następuje w czasie do 15 sekund. Zalecany jest do dozowania ciągłego, ale można go również dozować okresowo. Rozpuszczony w metanolu może być stosowany jako inhibitor hydratów i korozji.

\section{Inhibitor korozji Pachem-CWR-1021 - do dozowania okresowego, do ochrony odwiertów, urzadzeń wydobywczych i rurociagów transportujących rope naftowa w kopalniach ropy naftowej i gazu}

Inhibitor korozji Pachem-CWR-1021 jest inhibitorem korozji typu film forming, do dozowania okresowego w ilości 500-2000 mg/litr ropy i wody. Zawiera składniki tworzące na powierzchni instalacji trwałą warstewkę ochronną o grubości 20-50 mikrometrów, odporną na wymywanie ropą naftową i wodą złożową. Inhibitor korozji Pachem-CWR-1021 chroni przed działaniem siarkowodoru $\mathrm{H}_{2} \mathrm{~S}$, ditlenku węgla $\mathrm{CO}_{2}$ i chlorków. Film ochronny nie dopuszcza do powstawania wżerów oraz zapobiega korozji równomiernej. Inhibitor wykazuje doskonałe właściwości przeciwdziałania tworzeniu się emulsji ropy naftowej z wodą złożową. Inhibitor cechuje bardzo dobra rozpuszczalność w ropie naftowej, oleju napędowym, kondensacie gazowym i metanolu. Jest stosowany do wstępnego zabezpieczania odwiertów, pomp żerdziowych oraz rurociągów transportujących ropę naftową.

\section{Inhibitor korozji Pachem-CR-1012 - do ciaglego dozowania, do strumieni weglowodorowych $w$ instalacji destylacji rurowo-wieżowej DRW}

Inhibitor korozji Pachem-CR-1012 chroni przed korozją kolumny destylacyjne, układy kondensacyjne i rurociągi poprzez jego dozowanie do rur oparowych i orosień kolumn destylacyjnych. Wykazuje wysokie właściwości przeciwkorozyjne w stosunku do stali węglowych i stopowych już przy niskim dozowaniu - od 5-20 mg/litr, zalecane $15 \mathrm{mg} / \mathrm{litr}$, w sposób ciągły, w przeliczeniu na objętość benzyny surowej z DRW. Tworzy wyjątkowo trwałe warstewki chroniące przed korozją powierzchnie kolumn destylacyjnych, układów kondensacyjnych i rurociągów, doskonale zabezpiecza instalacje DRW przed korozją równomierną i wżerową. Wykazuje brak skłonności do pienienia, bardzo dobrą rozpuszczalność w lekkich frakcjach węglowodorowych - benzynach, tworzy jednorodny roztwór odporny

Tabela 2. Inhibitory korozji stosowane do badań

Table 2. Corrosion inhibitors used in the tests

\begin{tabular}{|c|c|c|c|c|}
\hline \multirow{2}{*}{$\begin{array}{c}\text { Inhibitory korozji } \\
\text { Parametr }\end{array}$} & \multicolumn{2}{|c|}{$\begin{array}{l}\text { Dla kopalni ropy naftowej - do ochrony przed koro- } \\
\text { zją odwiertów, ropociągów i urządzeń }\end{array}$} & \multirow{2}{*}{$\begin{array}{c}\text { Dla rafinerii - do } \\
\text { ochrony przed korozją } \\
\text { instalacji DRW } \\
\text { inhibitor korozji } \\
\text { Pachem-CR-1012 }\end{array}$} & \multirow{3}{*}{ Normy/metody } \\
\hline & $\begin{array}{l}\text { inhibitor korozji } \\
\text { Pachem-CWR-1011 }\end{array}$ & $\begin{array}{l}\text { inhibitor korozji } \\
\text { Pachem-CWR-1021 }\end{array}$ & & \\
\hline Dozowanie & ciągłe & okresowe & ciągłe & \\
\hline Wygląd w $20^{\circ} \mathrm{C}$ & $\begin{array}{l}\text { klarowna ciecz, } \\
\text { barwy bursztynowej }\end{array}$ & $\begin{array}{l}\text { klarowna ciecz, } \\
\text { barwy bursztynowej }\end{array}$ & $\begin{array}{l}\text { klarowna ciecz, } \\
\text { barwy bursztynowej }\end{array}$ & wizualnie \\
\hline Gęstość w $20^{\circ} \mathrm{C}\left[\mathrm{g} / \mathrm{cm}^{3}\right]$ & $0,80-0,85$ & $0,90-0,93$ & $0,85-0,95$ & PN-EN ISO 12185 \\
\hline Temperatura zapłonu $\left[{ }^{\circ} \mathrm{C}\right]$ & powyżej 12 & 32 & powyżej 10 & PN-EN ISO 2719 \\
\hline Temperatura płynięcia $\left[{ }^{\circ} \mathrm{C}\right]$ & -57 & poniżej -60 & -36 & PN-ISO 3016 \\
\hline Rozpuszczalność & $\begin{array}{l}\text { dysperguje w wodzie, roz- } \\
\text { puszcza się w ropie naftowej, } \\
\text { oleju napędowym i metanolu }\end{array}$ & $\begin{array}{c}\text { rozpuszcza się w ropie naf- } \\
\text { towej, w oleju napędowym } \\
\text { i metanolu, nie rozpuszcza } \\
\text { się w wodzie }\end{array}$ & $\begin{array}{l}\text { rozpuszcza się w benzy- } \\
\text { nie surowej DRW, tworząc } \\
\text { jednorodny roztwór, bez } \\
\text { osadów i zawiesin, odpor- } \\
\text { ny na przechowywanie }\end{array}$ & ASTM G 170-06 \\
\hline Zalecane dozowanie & $\begin{array}{l}\text { w sposób ciągły } 10-100 \text { ppm, } \\
\text { zalecane } 20-50 \text { ppm, w prze- } \\
\text { liczeniu na objętość ropy naf- } \\
\text { towej i wody złożowej lub } \\
\text { okresowo, co kilka dni, w ilo- } \\
\text { ści } 100-200 \text { ppm }\end{array}$ & $\begin{array}{l}\text { okresowo } 500-2000 \text { ppm, } \\
\text { w przeliczeniu na objętość } \\
\text { ropy naftowej i wody zło- } \\
\text { żowej }\end{array}$ & $\begin{array}{l}\text { w sposób ciągły } 5-20 \text { ppm, } \\
\text { zalecane } 15 \text { ppm, w przeli- } \\
\text { czeniu na objętość benzyny } \\
\text { surowej z DRW }\end{array}$ & - \\
\hline
\end{tabular}


Tabela 3. Właściwości fizykochemiczne stosowanych do badań rop naftowych

Table 3. Physicochemical properties of crude oils used for tests

\begin{tabular}{|l|c|c|}
\hline \multicolumn{1}{|c|}{ Wlaściwości } & $\begin{array}{c}\text { Ropa naftowa z kopalni ropy } \\
\text { naftowej i gazu ziemnego A }\end{array}$ & $\begin{array}{c}\text { Ropa naftowa z kopalni ropy } \\
\text { naftowej i gazu ziemnego B }\end{array}$ \\
\hline \hline Wygląd w $20^{\circ} \mathrm{C}$ & brunatna ciecz & brunatna ciecz \\
\hline Temperatura płynięcia $\left[{ }^{\circ} \mathrm{C}\right]$ & +3 & -38 \\
\hline Gęstość w $20^{\circ} \mathrm{C}\left[\mathrm{g} / \mathrm{cm}^{3}\right]$ & 0,840 & 0,812 \\
\hline Zawartość wody $[\%(v / v)]$ & 0,025 & 0,250 \\
\hline $\begin{array}{l}\text { Zawartość parafiny }[\%(m / m] / \\
\text { o temperaturze krzepnięcia }\left[{ }^{\circ} \mathrm{C}\right]\end{array}$ & $5,0 /+51$ & $1,9 /+53$ \\
\hline Zawartość asfaltenów $[\%(m / m)]$ & poniżej 0,01 & poniżej 0,01 \\
\hline Zawartość żywic $[\%(m / m)]$ & 6,2 & 3,0 \\
\hline Zawartość siarki $[\%(m / m)]$ & 0,950 & 0,078 \\
\hline
\end{tabular}

na przechowywanie. Znakomicie przeciwdziała powstawaniu emulsji (trzeciej fazy - tzw. międzyfazy) węglowodorów z parą wodną. Odbierana z kolumny destylacyjnej benzyna surowa jest klarowną cieczą, bez zanieczyszczeń i wody. Kondensat wodny z odstojnika jest przeźroczystą cieczą, bez zawiesin i osadów, o niskim chemicznym zapotrzebowaniu tlenu, z korzyścią dla środowiska naturalnego.

Do badań właściwości funkcjonalnych inhibitorów korozji do dozowania ciągłego i okresowego w kopalniach ropy naftowej wytypowano ropę naftową i wodę złożową pobrane w kopalni ropy i gazu, bez dodatków środków chemicznych, o właściwościach przedstawionych w tabelach 3 i 4.

Do badań właściwości funkcjonalnych inhibitorów korozji do dozowania ciągłego na instalacjach DRW w rafineriach wytypowano benzynę surową i wodę kondensatową pobrane na instalacji DRW, bez dodatków środków chemicznych, o właściwościach przedstawionych w tabelach 5 i 6.

Do oceny funkcjonalnych właściwości inhibitorów korozji wytypowano kilka znormalizowanych metod badań oraz jedną metodę nieznormalizowaną. Doboru dokonano, kierując się zaleceniami normy ASTM G 170-06 oraz wynikami własnych doświadczeń z badań nad korozją. Przebadano następujące właściwości funkcjonalne inhibitorów korozji:

- badanie właściwości przeciwkorozyjnych inhibitora korozji oraz szybkości tworzenia się osadu na stalowych płytkach według NACE 1D182;

- kompatybilność inhibitora korozji z nośnikami: wodą złożową lub benzyną surową według ASTM G 170-06;

- skłonność do emulgowania inhibitora korozji z mieszanką ropy naftowej z wodą złożową lub benzyny surowej z wodą kondensatową - ASTM G 170-06;

- grubość warstwy ochronnej-według metodyki INiG - PIB.
Tabela 5. Właściwości fizykochemiczne stosowanej do badań benzyny surowej z DRW w rafinerii A

Table 5. Physicochemical properties of used raw gasoline from CDU in refinery A

\begin{tabular}{|l|c|}
\hline \multicolumn{1}{|c|}{ Właściwości } & $\begin{array}{c}\text { Benzyna surowa } \mathbf{z} \text { instalacji DRW } \\
\text { w rafinerii A }\end{array}$ \\
\hline \hline Wygląd w $20^{\circ} \mathrm{C}$ & przeźroczysta, jasna ciecz \\
\hline Temperatura płynięcia $\left[{ }^{\circ} \mathrm{C}\right]$ & poniżej -60 \\
\hline Gęstość, $15^{\circ} \mathrm{C}\left[\mathrm{g} / \mathrm{cm}^{3}\right]$ & 0,740 \\
\hline Zawartość siarki $[\%(\mathrm{~m} / \mathrm{m})]$ & 0,15 \\
\hline Początek destylacji $\left[{ }^{\circ} \mathrm{C}\right]$ & 30 \\
\hline Koniec destylacji $\left[{ }^{\circ} \mathrm{C}\right]$ & 200 \\
\hline
\end{tabular}

Tabela 6. Właściwości fizykochemiczne stosowanej do badań wody kondensatowej pobranej z instalacji DRW w rafinerii A

Table 6. Physicochemical properties of used condensate water from $\mathrm{CDU}$ in refinery $\mathrm{A}$

\begin{tabular}{|l|c|}
\hline \multicolumn{1}{|c|}{ Wlaściwości } & $\begin{array}{c}\text { Woda kondensatowa } \mathbf{z} \text { instalacji DRW } \\
\text { w rafinerii A }\end{array}$ \\
\hline \hline Wygląd w $20^{\circ} \mathrm{C}$ & klarowna, bezbarwna ciecz \\
\hline Gęstość w $20^{\circ} \mathrm{C}\left[\mathrm{g} / \mathrm{cm}^{3}\right]$ & 0,989 \\
\hline Odczyn $\mathrm{pH}$ & 4,0 \\
\hline
\end{tabular}


Badania wtaściwości przeciwkorozyjnych inhibitora korozji oraz szybkości tworzenia się osadu na stalowych phytkach

Wheel Test Method Used for Evaluation of Film-Persistent Corrosion Inhibitors for Oilfield Applications - wedtug NACE $1 D 182$.

Jest to konwencjonalna metoda badania ubytku masy, stosowana do oceny wydajności inhibitora poprzez symulację ciągłego przepływu medium korozyjnego. Do butelek testowych wlewano ropę naftową/ benzynę surową, zawierające najczęściej siarkowodór i dwutlenek węgla oraz wodę, pobrane w kopalni ropy naftowej lub rafinerii. Wodę z ropa/ benzyną surową mieszano, następnie wprowadzano inhibitor korozji w ilości 10-100 mg/litr, po czym umieszczano w nich płytki stalowe Shimstock o wymiarach $0,13 \times 12,7 \times 76 \mathrm{~mm}$. Do butelek testowych nad powierzchnię cieczy dozowano $\mathrm{CO}_{2}$, następnie butelki szczelnie zamykano i umieszczano w termostacie w temperaturze $65^{\circ} \mathrm{C}$, w aparacie obrotowym, który obracał się z prędkością $15 \mathrm{obr} / \mathrm{min}$. Test prowadzono przez minimum 72 godziny. Po badaniu płytki metalu oczyszczano i oceniano ubytek masy płytki, ilość osadów oraz ewentualną obecność korozji wżerowej.

\section{Inhibitory korozji dla kopalni ropy naftowej}

- $10-50 \%(v / v)$ ropa naftowa

- $\quad 50-90 \%(v / v)$ woda złożowa

- nasycone $\mathrm{CO}_{2}$ i $\mathrm{H}_{2} \mathrm{~S}$

- szybkość obrotu butelek: 15 RPM

- płytki ze stali Shimstock

- temperatura: $65^{\circ} \mathrm{C}$

- czas badania: 72 godziny

- ciśnienie: 1 atm

\section{Inhibitory korozji dla rafinerii}

- $\quad 10-50 \%(v / v)$ benzyna surowa

- $50-90 \%(v / v)$ woda kondensatowa

- nasycone $\mathrm{CO}_{2} \mathrm{i} \mathrm{H}_{2} \mathrm{~S}$

- szybkość obrotu butelek: 15 RPM

- płytki ze stali Shimstock

- temperatura: $65^{\circ} \mathrm{C}$

- czas badania: 72 godziny
- ciśnienie: $1 \mathrm{~atm}$

Test służył ocenie zdolności inhibitora do tworzenia filmu ochronnego na powierzchni metalu oraz jego trwałości na wymywanie ropą naftową/ benzyną surową i wodą.

\section{Kompatybilność inhibitora korozji z nośnikami: woda zlożowa lub benzyna surowa}

Standard Guide for Evaluating and Qualifying Oilfield and Refinery Corrosion Inhibitors in the Laboratory wedtug ASTM G 170-06.

Do cylindra o pojemności $100 \mathrm{ml}$ dozowano wodę złożową/ benzynę surową, a następnie obydwie fazy intensywnie mieszano i obserwowano zmianę wyglądu w zależności od temperatury i czasu przechowywania.

\section{Skłonność do emulgowania inhibitora korozji z mieszanka ropy naftowej z woda zlożowa lub benzyny surowej \\ z kondensatem wodnym}

Standard Guide for Evaluating and Qualifying Oilfield and Refinery Corrosion Inhibitors in the Laboratory według ASTM G 170-06.

Badanie wykonywano, mieszając węglowodory z wodą i wprowadzając inhibitor korozji w ilości znacznie przewyższającej jego standardowe dozowanie. Każdą próbkę mieszano intensywnie, po czym odstawiano. Obserwowano wygląd warstw: węglowodorowej i wodnej oraz wygląd granicy międzyfazowej po 15 sekundach i 15 minutach. Następnie dokonywano porównania z próbą ślepą (bez inhibitora). Oceniono również czas potrzebny na pełne oddzielenie się obu faz.

\section{Grubość warstwy ochronnej}

Oznaczanie grubości powłoki ochronnej- metodyka INiG - PIB.

Płytkę o wymiarach $50 \times 50 \times 3 \mathrm{~mm}$ czyszczono papierem ściernym, przemywano rozpuszczalnikami, suszono i ważono na wadze analitycznej. Następnie zanurzano w inhibitorze korozji w temperaturze otoczenia na 3 minuty, po czym wyjmowano płytkę pokrytą inhibitorem korozji i pozostawiano na 3 godziny w celu ocieknięcia nadmiaru inhibitora i odparowania rozpuszczalnika. Po zakończeniu badania ponow-

Badanie trwałości filmu ochronnego wykonywano w dwóch etapach: W pierwszym etapie, po zadozowaniu $9000 \mathrm{mg}$ inhibitora korozji na litr mieszaniny ropa-woda, przez 2 godziny na płytce stalowej Shimstock tworzył się film ochronny. Następnie tak przygotowaną płytkę testową przenoszono bezdotykowo do kolejnej testowej butelki, gdzie przez 72 godziny przebywała w mieszance ropa-woda $\mathrm{z}$ dodatkiem $\mathrm{CO}_{2} \mathrm{i} / \mathrm{lub} \mathrm{H}_{2} \mathrm{~S}$. nie ważono płytkę. Mase powłoki ochronnej wyznaczano według wzoru: $m=m_{2}-m_{1}$, gdzie $m_{2}$ to masa płytki z powłoką ochronną po odparowaniu rozpuszczalnika, a $m_{1}$ to wyjściowa masa płytki. Grubość powłoki ochronnej $(\mu \mathrm{m})$ obliczano według wzoru: $g=(m \cdot 10000):(q \cdot s)$, gdzie $m$ - masa powłoki ochronnej, $q$ - gęstość środka, a $s$ - całkowite pole powierzchni płytki. 


\section{Wyniki badań laboratoryjnych inhibitora korozji Pachem-CWR-1011 do dozowania ciągłego do ochrony odwiertów i ropociągów}

Przeprowadzono badania korozyjne z udziałem inhibitora korozji Pachem-CWR-1011 według NACE 1D182 Wheel Test Method Used for Evaluation of Film-Persistent Corrosion Inhibitors for Oilfield Applications. Badania wykonano dla wody złożowej i ropy naftowej z kopalni ropy A, zmieszanych w stosunku 90:10\% (v/v), w obecności $\mathrm{CO}_{2}$. Badanie szybkości korozji przeprowadzono w jednym etapie, dozując $25 \mathrm{mg} /$ litr inhibitora korozji do mieszanki ropa-woda, czas ekspozycji: 72 godziny. Wyniki badań korozyjnych wraz z wyglądem płytek testowych po badaniu przedstawiono w tabeli 7, a w tabeli 8 zaprezentowano wygląd butelek testowych po badaniu korozyjnym.

Tabela 7. Wyniki badań korozyjnych inhibitora korozji Pachem-CWR-1011 do dozowania ciągłego do ochrony odwiertów i ropociągów według NACE 1 D182

Table 7. Corrosion tests results of the corrosion inhibitor Pachem-CWR-1011 for continuous dosing for the protection of wells and oil pipelines according to NACE $1 \mathrm{D} 182$

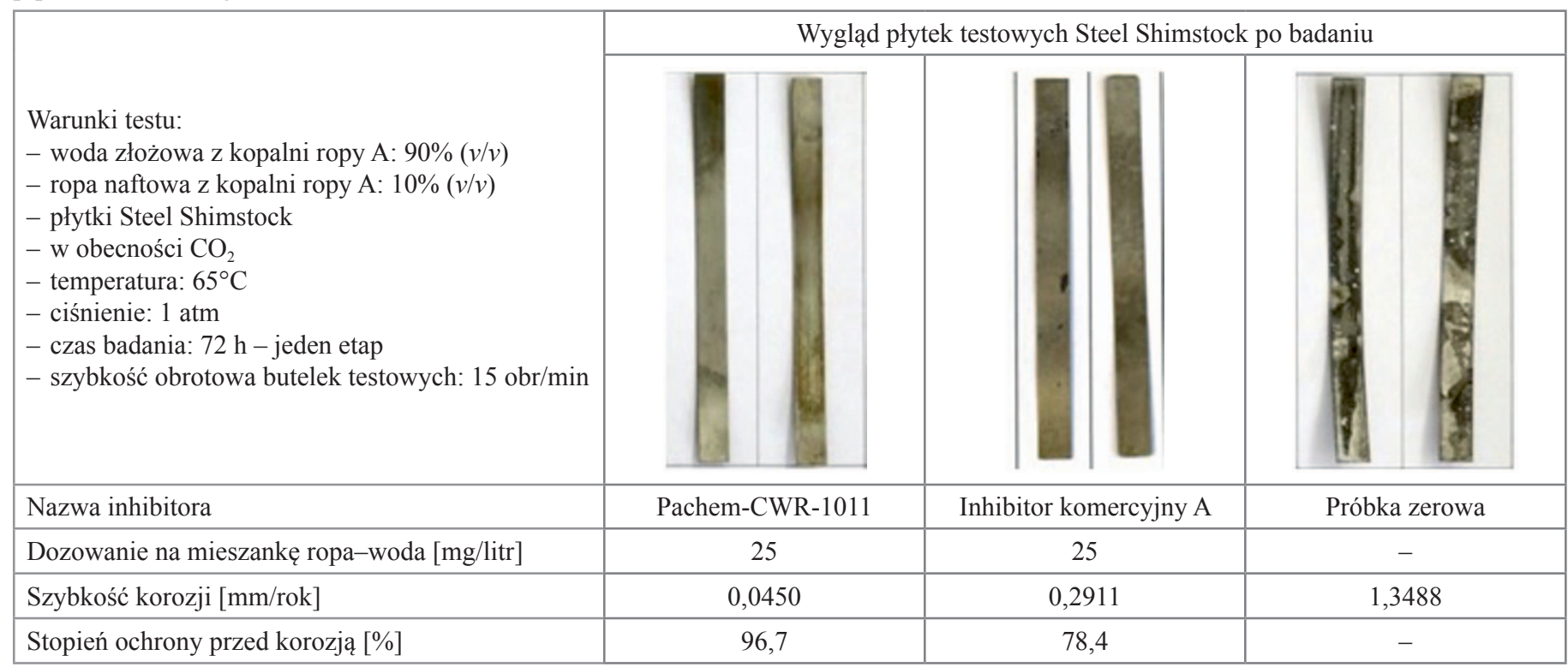

Tabela 8. Wygląd butelek testowych po badaniu korozyjnym z udziałem inhibitora korozji Pachem-CWR-1011 do dozowania ciągłego do ochrony odwiertów i ropociągów według NACE 1D182

Table 8. Appearance of test bottles after a corrosion test with the use of the Pachem-CWR-1011 corrosion inhibitor for continuous dosing for the protection of wells and oil pipelines according to NACE 1 D182

\begin{tabular}{|c|c|c|c|}
\hline \multirow[b]{2}{*}{$\begin{array}{l}\text { Warunki testu: } \\
\text { - woda złożowa z kopalni ropy A: } 90 \%(v / v) \\
\text { - ropa naftowa z kopalni ropy A: } 10 \%(v / v) \\
\text { - płytki Steel Shimstock } \\
\text { - w obecności } \mathrm{CO}_{2} \\
\text { - temperatura: } 65^{\circ} \mathrm{C} \\
\text { - ciśnienie: } 1 \mathrm{~atm} \\
\text { - czas badania: } 72 \mathrm{~h} \text { - jeden etap } \\
\text { - szybkość obrotowa butelek testowych: } 15 \mathrm{obr} / \mathrm{min}\end{array}$} & \multicolumn{3}{|c|}{ Wygląd faz ropa-woda po badaniu } \\
\hline & 8 & & 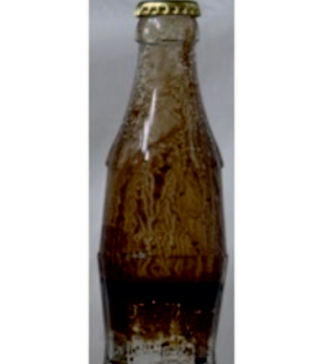 \\
\hline Nazwa inhibitora & Pachem-CWR-1011 & Inhibitor komercyjny A & Próbka zerowa \\
\hline Dozowanie na mieszankę ropa-woda [mg/litr] & 25 & 25 & - \\
\hline Wygląd faz po procesie odstawania po 15 minutach & $\begin{array}{l}\text { wyraźny rozdział ropy naf- } \\
\text { towej od wody, nie stwier- } \\
\text { dzono międzyfazy (emulsji) }\end{array}$ & $\begin{array}{l}\text { niepełny rozdział, ropa naf- } \\
\text { towa wchłonęła wodę, } \\
\text { zwiększając dwukrotnie } \\
\text { swoją objętość, nie stwier- } \\
\text { dzono międzyfazy (emulsji) }\end{array}$ & $\begin{array}{c}\text { wyraźny rozdział ropy } \\
\text { naftowej od wody, nie } \\
\text { stwierdzono międzyfazy } \\
\text { (emulsji) }\end{array}$ \\
\hline
\end{tabular}


Tabela 9. Wyniki badań skłonności do emulgowania dla inhibitora korozji Pachem-CWR-1011 do dozowania ciągłego do ochrony odwiertów i ropociągów według ASTM G 170-06

Table 9. Results of emulsification tendency tests for the corrosion inhibitor Pachem-CWR-1011 for continuous dosing for the protection of wells and oil pipelines according to ASTM G 170-06

\begin{tabular}{|c|c|c|c|}
\hline \multirow[b]{2}{*}{$\begin{array}{l}\text { Warunki testu: } \\
\text { - ropa naftowa z kopalni ropy B: } 75 \%(v / v) \\
\text { - woda korozyjna według NACE } 1 \mathrm{D} 182: 25 \%(v / v) \\
\text { - temperatura: } 20^{\circ} \mathrm{C} \\
\text { - ciśnienie: } 1 \text { atm } \\
\text { - } 100 \text { ostrych wstrząśnięć } \\
\text { - czas odstawania: } 15 \text { minut }\end{array}$} & \multicolumn{3}{|c|}{ Wygląd faz ropa-woda po badaniu } \\
\hline & & & \\
\hline Nazwa inhibitora & Pachem-CWR-1011 & Inhibitor komercyjny A & Próbka zerowa \\
\hline Dozowanie na mieszankę ropa-woda [mg/litr] & 50 & 50 & - \\
\hline Wygląd faz po procesie odstawania po 15 minutach & $\begin{array}{c}\text { wyraźny rozdział ropy } \\
\text { naftowej od wody, nie } \\
\text { stwierdzono międzyfazy } \\
\text { (emulsji) }\end{array}$ & $\begin{array}{l}\text { niepełny rozdział ropy naf- } \\
\text { towej od wody, wzrost ilo- } \\
\text { ści ropy, zmniejszenie ilo- } \\
\text { ści wody, } 5 \mathrm{ml} \text { emulsji }\end{array}$ & $\begin{array}{l}100 \text { ml emulsji, brak wy- } \\
\text { dzielonej wody }\end{array}$ \\
\hline
\end{tabular}

Przeprowadzono badania skłonności do emulgowania mieszanki ropa naftowa-woda złożowa z udziałem inhibitora korozji Pachem-CWR-1011 według ASTM G 170-06 Standard Guide for Evaluating and Qualifying Oilfield and Refinery Corrosion Inhibitors in the Laboratory. Badania wykonano dla ropy naftowej z kopalni ropy B i wody korozyjnej według NACE 1D182, zmieszanych w stosunku 75:25\% (v/v). Badanie skłonności do emulgowania wykonano, dozując $50 \mathrm{mg} /$ litr inhibitora korozji do mieszanki ropy z wodą. Wyniki badań przedstawiono w tabeli 9.

\section{Wyniki badań laboratoryjnych inhibitora korozji Pachem-CWR-1021 do dozowania okresowego dla ochrony odwiertów i ropociągów}

Przeprowadzono badania korozyjne z udziałem inhibitora korozji do dozowania okresowego Pachem-CWR-1021 według NACE 1D182 Wheel Test Method Used for Evaluation of Film-Persistent Corrosion Inhibitors for Oilfield Applications. Badania wykonano dla wody złożowej i ropy naftowej z kopalni ropy A, zmieszanych w stosunku 90:10\% $(v / v)$, w obecności $\mathrm{CO}_{2}$. Badanie szybkości korozji przeprowadzono w dwóch etapach. W pierwszym etapie do butelek testowych zawierających płytki Steel Shimstock zadozowano inhibitor w ilości $9000 \mathrm{mg} /$ litr mieszanki ropa-woda, a czas ekspozycji płytek na medium korozyjne $\mathrm{z}$ inhibitorem wynosił 2 godziny. Następnie bezdotykowo przeniesiono płytki Steel Shimstock z utworzoną na nich powłoką ochronną do kolejnych butelek, a czas ekspozycji na medium korozyjne z inhibitorem wynosił 72 godziny. W drugim etapie badania nie dozowano już inhibitora korozji, a płytki stalowe były chronione przez powłokę ochronną wytworzoną w pierwszym etapie. Wyniki badań korozyjnych przedstawiono w tabelach 10 i 11, w tym wygląd płytek Steel Shimstock po badaniu i wygląd faz ropa-woda, określający skłonność do emulgowania.

Przeprowadzono badania grubości warstwy ochronnej utworzonej przez inhibitor korozji Pachem-CWR-1021, według metody INiG - PIB. Wyniki badań przedstawiono w tabeli 12 .

\section{Wyniki badań laboratoryjnych inhibitora korozji Pachem-CR-1012 do ochrony instalacji destylacji rurowo-wieżowej DRW}

Przeprowadzono dynamiczne badania korozyjne z udziałem inhibitora korozji Pachem-CR-1012 według NACE 1 D182 Wheel Test Method Used for Evaluation of Film-Persistent Corrosion Inhibitors for Oilfield Applications. Badanie wykonano dla benzyny surowej i kondensatu wodnego pobranych $\mathrm{z}$ rafinerii, zmieszanych $\mathrm{w}$ stosunku $50: 50 \%(v / v)$, w obecności $\mathrm{CO}_{2} \mathrm{w}$ temperaturze $65^{\circ} \mathrm{C}$, w czasie 72 godzin, przy dozowaniu $10 \mathrm{mg} /$ litr benzyny. Wyniki badań korozyjnych przedstawiono w tabelach 13 i 14.

Przeprowadzono statyczne badanie korozyjne z udziałem inhibitora korozji Pachem-CR-1012 wedhug PN-H-04601 Badanie laboratoryjne w cieczach i roztworach o temperaturze otoczenia. 
Tabela 10. Wyniki badań korozyjnych inhibitora korozji Pachem-CWR-1021 do dozowania okresowego dla ochrony odwiertów i ropociągów według NACE 1D182

Table 10. Corrosion test results for the Pachem-CWR-1021 corrosion inhibitor for periodic dosing for the protection of wells and oil pipelines, according to NACE 1D182

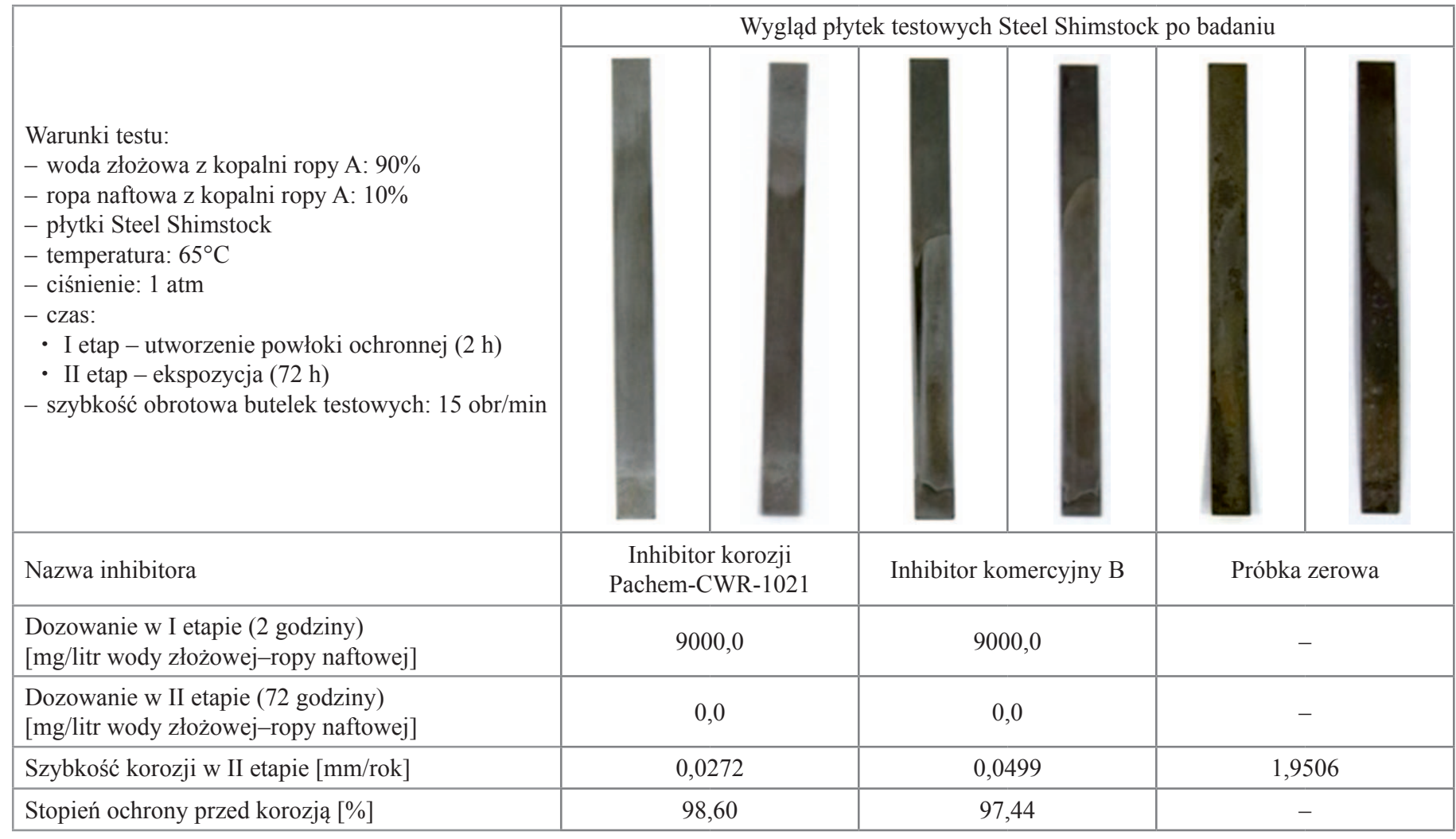

Tabela 11. Wygląd butelek testowych po badaniu korozyjnym z udziałem inhibitora korozji Pachem-CWR-1021 do dozowania okresowego dla ochrony odwiertów i ropociągów, według NACE 1 D182

Table 11. Appearance of test bottles after a corrosion test with a corrosion inhibitor Pachem-CWR-1021 for periodic dosing for the protection of wells and oil pipelines, according to NACE 1 D182

\begin{tabular}{|c|c|c|c|}
\hline \multirow[b]{2}{*}{$\begin{array}{l}\text { Warunki testu: } \\
\text { - woda złożowa z kopalni ropy A: } 90 \% \\
\text { - ropa naftowa z kopalni ropy A: } 10 \% \\
\text { - płytki Steel Shimstock } \\
\text { - temperatura: } 65^{\circ} \mathrm{C} \\
\text { - ciśnienie: } 1 \mathrm{~atm} \\
\text { - czas: } \\
\text { - I etap - utworzenie powłoki ochronnej }(2 \mathrm{~h}) \\
\text { - II etap - ekspozycja }(72 \mathrm{~h}) \\
\text { - szybkość obrotowa butelek testowych: } 15 \mathrm{obr} / \mathrm{min}\end{array}$} & \multicolumn{3}{|c|}{ Wygląd faz ropa-woda po badaniu } \\
\hline & 11 & 4 & 8 \\
\hline Nazwa inhibitora & $\begin{array}{c}\text { Inhibitor korozji } \\
\text { Pachem-CWR-1021 }\end{array}$ & Inhibitor komercyjny B & Próbka zerowa \\
\hline $\begin{array}{l}\text { Dozowanie w I etapie ( } 2 \text { godziny) } \\
\text { [mg/litr wody złożowej-ropy naftowej] }\end{array}$ & 9000,0 & 9000,0 & 0,0 \\
\hline $\begin{array}{l}\text { Wygląd butelek testowych po I etapie po wyjęciu } \\
\text { płytek testowych }\end{array}$ & $\begin{array}{c}\text { wyraźny rozdział ropy } \\
\text { naftowej od wody, nie } \\
\text { stwierdzono międzyfazy } \\
\text { (emulsji) }\end{array}$ & $\begin{array}{l}\text { niepełny rozdział, ropa naf- } \\
\text { towa wchłonęła wodę, } \\
\text { zwiększając dwukrotnie } \\
\text { swoją objętość, nie stwier- } \\
\text { dzono międzyfazy (emulsji) }\end{array}$ & $\begin{array}{c}\text { wyraźny rozdział ropy } \\
\text { naftowej od wody, nie } \\
\text { stwierdzono międzyfazy } \\
\text { (emulsji) }\end{array}$ \\
\hline
\end{tabular}


Tabela 12. Badanie grubości warstwy ochronnej inhibitora korozji Pachem-CWR-1021 do dozowania okresowego dla ochrony odwiertów i ropociągów według metody $\mathrm{INiG}-\mathrm{PIB}$

Table 12. Testing of the protective layer thickness of the corrosion inhibitor Pachem-CWR-1021 for periodic dosing for the protection of wells and oil pipelines according to the INiG - PIB method

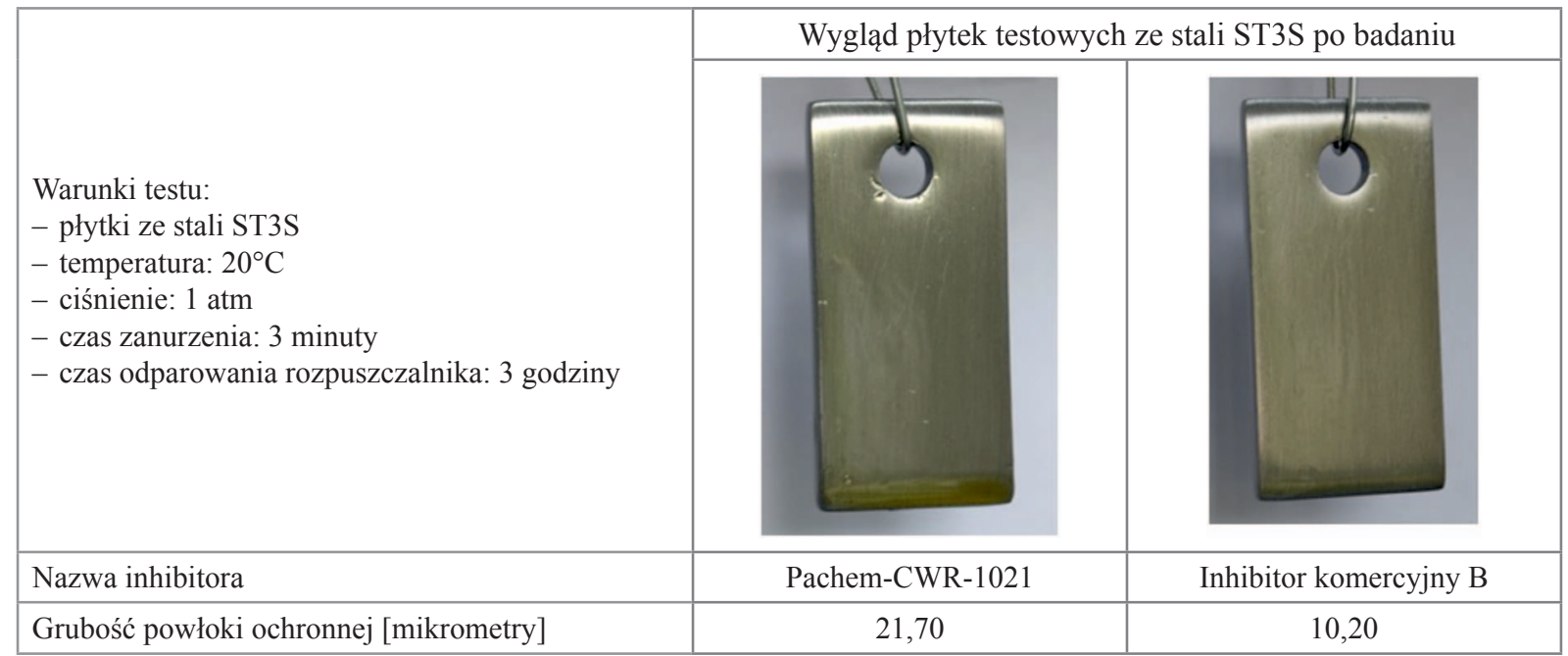

Tabela 13. Wyniki badania korozyjnego dynamicznego z udziałem inhibitora korozji Pachem-CR-1012 do ochrony instalacji destylacji rurowo-wieżowej DRW według NACE 1D182

Table 13. The results of the dynamic corrosion test with the use of the Pachem-CR-1012 corrosion inhibitor for the protection of the CDU, according to NACE 1 D182

\begin{tabular}{|c|c|c|c|}
\hline \multirow[b]{2}{*}{$\begin{array}{l}\text { Warunki testu: } \\
\text { - benzyna surowa zawierająca } \mathrm{H}_{2} \mathrm{~S}, \mathrm{z} \text { rafinerii A: } \\
50 \%(\mathrm{v} / \mathrm{v}) \\
\text { - woda kondensatowa z rafinerii A: } 50 \%(\mathrm{v} / \mathrm{v}) \\
\text { - płytki Steel Shimstock } \\
\text { - w obecności } \mathrm{CO}_{2} \\
\text { - temperatura: } 65^{\circ} \mathrm{C} \\
\text { - ciśnienie: } 1 \mathrm{~atm} \\
\text { - czas ekspozycji: } 72 \mathrm{~h} \text { - jeden etap } \\
\text { - szybkość obrotowa butelek testowych: } 15 \mathrm{obr} / \mathrm{min}\end{array}$} & \multicolumn{3}{|c|}{ Wygląd płytek testowych Steel Shimstock po badaniu } \\
\hline & & 8 & \\
\hline Nazwa inhibitora & Pachem-CR-1012 & Inhibitor komercyjny $\mathrm{C}$ & Próbka zerowa \\
\hline Dozowanie [mg/litr benzyny surowej] & 10 & 10 & 0 \\
\hline Szybkość korozji [mm/rok] & 0,11 & 1,01 & 2,50 \\
\hline Stopień ochrony przed korozją [\%] & 96,0 & 59,6 & - \\
\hline
\end{tabular}

Badanie wykonano dla benzyny surowej i kondensatu wodnego pobranych z rafinerii, zmieszanych w stosunku 80:20\% $(v / v)$, w temperaturze $20^{\circ} \mathrm{C}$, w czasie 24 godzin, przy dozowaniu $15 \mathrm{mg} /$ litr benzyny. Wyniki badań korozyjnych przedstawiono w tabeli 14.

Przeprowadzono badania skłonności do emulgowania mieszanki ropa naftowa-woda złożowa z udziałem inhibitora korozji Pachem-CR-1012 według ASTM G 170-06 Standard Guide for Evaluating and Qualifying Oilfield and Refinery Corrosion Inhibitors in the Laboratory. Badania wykonano dla benzyny surowej i kondensatu wodnego pobranych $\mathrm{z}$ rafinerii A, zmieszanych w stosunku 80:20\% (v/v), w temperaturze $20^{\circ} \mathrm{C}$. Badanie skłonności do emulgowania przeprowadzono, dozując $20 \mathrm{mg} /$ litr inhibitora. Wyniki badań przedstawiono w tabeli 16.

\section{Podsumowanie i wnioski}

\section{Inhibitor korozji Pachem-CWR-1011}

Przeprowadzono badania korozyjne $\mathrm{z}$ udziałem inhibitora korozji Pachem-CWR-1011 do dozowania ciągłego do ochrony 
Tabela 14. Wyniki badania korozyjnego dynamicznego z udziałem inhibitora korozji Pachem-CR-1012 do ochrony instalacji destylacji rurowo-wieżowej DRW według NACE 1D182

Table 14. The results of the dynamic corrosion test with the use of the Pachem-CR-1012 corrosion inhibitor for the protection of the CDU, according to NACE 1D182

\begin{tabular}{|c|c|c|c|}
\hline \multirow[b]{2}{*}{$\begin{array}{l}\text { Warunki testu: } \\
\text { - benzyna surowa zawierająca } \mathrm{H}_{2} \mathrm{~S}, \mathrm{z} \text { rafinerii A: } \\
50 \%(v / v) \\
\text { - kondensat wodny z rafinerii A: } 50 \%(v / v) \\
\text { - płytki Steel Shimstock } \\
\text { - w obecności } \mathrm{CO}_{2} \\
\text { - temperatura: } 65^{\circ} \mathrm{C} \\
\text { - ciśnienie: } 1 \mathrm{~atm} \\
\text { - czas: } 72 \mathrm{~h} \text { - jeden etap } \\
\text { - szybkość obrotowa butelek testowych: } 15 \mathrm{obr} / \mathrm{min}\end{array}$} & \multicolumn{3}{|c|}{ Wygląd faz benzyna surowa-woda kondensatowa po badaniu } \\
\hline & 1112 & 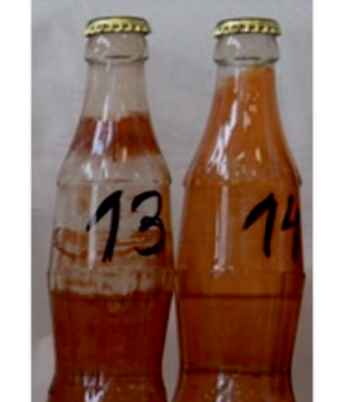 & $\sum_{i=1}^{\infty}$ \\
\hline Nazwa inhibitora & Pachem-CR-1012 & Inhibitor komercyjny $\mathrm{C}$ & Próbka zerowa \\
\hline Dozowanie [mg/litr benzyny surowej] & 10 & 10 & 0 \\
\hline Wygląd benzyny surowej & przeźroczysta ciecz & przeźroczysta ciecz & przeźroczysta ciecz \\
\hline Wygląd wody kondensatowej & $\begin{array}{l}\text { przeźroczysta ciecz, brak } \\
\text { osadów korozyjnych }\end{array}$ & $\begin{array}{l}\text { lekko mętna ciecz, dużo } \\
\text { osadów rdzawych na ścia- } \\
\text { nach butelki testowej }\end{array}$ & $\begin{array}{l}\text { przeźroczysta ciecz, bardzo } \\
\text { dużo osadów rdzawych na } \\
\text { ścianach butelki testowej }\end{array}$ \\
\hline
\end{tabular}

Tabela 15. Wyniki badania korozyjnego statycznego z udziałem inhibitora korozji Pachem-CR-1012 do ochrony instalacji destylacji rurowo-wieżowej DRW według PN-H-04601

Table 15. The results of the static corrosion test with the use of the Pachem-CR-1012 corrosion inhibitor for the protection of the CDU, according to PN-H-04601 standard

\begin{tabular}{|c|c|c|c|}
\hline \multirow[b]{2}{*}{$\begin{array}{l}\text { Warunki testu: } \\
\text { - benzyna surowa zawierająca } \mathrm{H}_{2} \mathrm{~S}, \mathrm{z} \text { rafinerii A: } \\
80 \%(\mathrm{v} / \mathrm{v}) \\
\text { - woda kondensatowa z rafinerii A: } 20 \% \\
\text { - płytki ze stali ST3S } \\
\text { - temperatura: } 20^{\circ} \mathrm{C} \\
\text { - ciśnienie: } 1 \mathrm{~atm} \\
\text { - czas: } 96 \mathrm{~h}\end{array}$} & \multicolumn{3}{|c|}{ Wygląd płytek testowych ze stali ST3S po badaniu } \\
\hline & 6 & 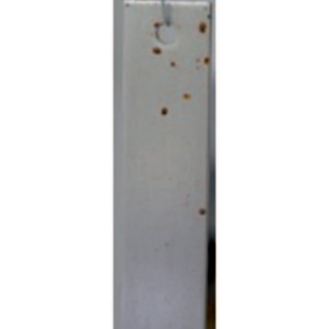 & $\begin{array}{l}8 \\
1 \\
1 \\
\vdots \\
0\end{array}$ \\
\hline Nazwa inhibitora & Pachem-CR-1012 & Inhibitor komercyjny $\mathrm{C}$ & Próbka zerowa \\
\hline Dozowanie [mg/litr benzyny surowej] & 15 & 15 & - \\
\hline Szybkość korozji [mm/rok] & 0,003 & 0,71 & 1,95 \\
\hline Stopień ochrony przed korozją [\%] & 99,8 & 63,6 & - \\
\hline Wygląd benzyny surowej po badaniu & przeźroczysta ciecz & lekko mętna ciecz & przeźroczysta ciecz \\
\hline Wygląd wody po badaniu & przeźroczysta ciecz & lekko mętna ciecz & $\begin{array}{c}\text { przeźroczysta ciecz, duża } \\
\text { ilość osadów rdzawych na } \\
\text { dnie }\end{array}$ \\
\hline
\end{tabular}

odwiertów i ropociągów według NACE 1D182. Badania wykonano dla wody złożowej i ropy naftowej z kopalni ropy A, zmieszanych w stosunku 90:10\% (v/v), w obecności $\mathrm{CO}_{2}$. Badanie szybkości korozji przeprowadzono w jednym etapie, dozując $25 \mathrm{mg} /$ litr inhibitora korozji do mieszanki ropa-woda, czas ekspozycji wynosił 72 godziny. Badania wykazały, że przy takim dozowaniu inhibitora szybkość korozji testowych płytek Steel Shimstock wynosiła 0,0450 mm/rok, a stopień 
Tabela 16. Wyniki badań skłonności do emulgowania inhibitora korozji Pachem-CR-1012 do ochrony instalacji destylacji rurowo-wieżowej DRW według ASTM G 170-06 - metoda w butelkach Simax

Table 16. The results of emulsion formation tendency tests of the corrosion inhibitor Pachem-CR-1012 for the protection of the CDU, according to ASTM G 170-06 - the Simax bottles method

\begin{tabular}{|c|c|c|c|}
\hline \multirow[b]{2}{*}{$\begin{array}{l}\text { Warunki testu: } \\
\text { - benzyna surowa zawierająca } \mathrm{H}_{2} \mathrm{~S}, \mathrm{z} \text { rafinerii A: } \\
\quad 80 \%(v / v) \\
\text { - kondensat wodny z rafinerii A: } 20 \%(v / v) \\
\text { - } 100 \text { ostrych wstrząśnięć } \\
\text { - temperatura: } 20^{\circ} \mathrm{C} \\
\text { - czas odstawania: } 15 \text { minut }\end{array}$} & \multicolumn{3}{|c|}{ Wygląd faz benzyna-woda po badaniu } \\
\hline & $e^{2}$ & 2 & $-5=4$ \\
\hline Nazwa inhibitora & Pachem-CR-1012 & Inhibitor komercyjny $\mathrm{C}$ & Próbka zerowa \\
\hline Dozowanie inhibitora [mg/litr] & 20 & 20 & - \\
\hline Wygląd benzyny surowej po badaniu & przeźroczysta ciecz & lekko mętna ciecz & przeźroczysta ciecz \\
\hline Wygląd wody po badaniu & przeźroczysta ciecz & $\begin{array}{l}\text { lekko mętna ciecz, } \\
\text { w postaci emulsji }\end{array}$ & przeźroczysta ciecz \\
\hline
\end{tabular}

ochrony przed korozją kształtował się na poziomie $96,7 \%$. Po badaniu zaobserwowano wyraźny rozdział ropy naftowej od wody, nie stwierdzono obecności międzyfazy (emulsji). W przypadku inhibitora komercyjnego A uznanej firmy szybkość korozji testowych płytek Steel Shimstock wynosiła $0,2911 \mathrm{~mm} / \mathrm{rok}$, a stopień ochrony przed korozją kształtował się na poziomie $78,4 \%$. Po badaniu stwierdzono niepełny rozdział faz, ropa naftowa wchłonęła wodę, zwiększając dwukrotnie swoją objętość.

Przeprowadzono badania skłonności do emulgowania mieszanki ropa naftowa-woda $\mathrm{z}$ udziałem inhibitora korozji Pachem-CWR-1011 w porównaniu do inhibitora komercyjnego A uznanej firmy - według ASTM G 170-06. Badania wykonano dla ropy naftowej z kopalni ropy B i wody korozyjnej sporządzonej według NACE 1D182, zmieszanych w stosunku $75: 25 \%(v / v)$. Badanie skłonności do emulgowania przeprowadzono, dozując $50 \mathrm{mg} /$ litr inhibitora korozji do mieszanki ropy z wodą. W przypadku inhibitora korozji Pachem-CWR-1011 stwierdzono wyraźny rozdział ropy naftowej od wody, a w przypadku inhibitora komercyjnego A uznanej firmy - niepełny rozdział ropy naftowej od wody, wzrost ilości ropy, świadczący o wchłonięciu znacznych ilości wody, co będzie miało negatywny wpływ na jakość wydobywanej ropy naftowej, zwiększenie jej lepkości oraz silnego oddziaływania korozyjnego, z uwagi na wysoką zawartość chlorków w wodzie.

Podsumowując, przeprowadzone badania wykazały wysokie właściwości przeciwkorozyjne inhibitora korozji PachemCWR-1011 do dozowania ciągłego do ochrony odwiertów i ropociągów oraz znakomite właściwości przeciwdziałania tworzeniu się emulsji ropa-woda, z korzyścią dla jakości ropy naftowej oraz dla środowiska. Inhibitor korozji Pachem-CWR-1011 wykazuje wysokie właściwości przeciwkorozyjne już przy niskim dozowaniu $25 \mathrm{mg} /$ litr, tworzy na powierzchni ze stali węglowej wyjątkowo trwałe warstewki chroniące stal przed korozją równomierną i wżerową. Dodatkową korzystną cechą inhibitora jest jego niska lepkość i niska temperatura płynięcia.

\section{Inhibitor korozji do dozowania okresowego Pachem-CWR-1021}

Przeprowadzono badania korozyjne z udziałem inhibitora korozji do dozowania okresowego Pachem-CWR-1021 według NACE 1D182. Badania wykonano dwuetapowo, dla wody złożowej i ropy naftowej z kopalni ropy A, zmieszanych w stosunku 90:10\% (v/v), w obecności $\mathrm{CO}_{2}$. Badania wykazały, że po wytworzeniu w I etapie powłoki ochronnej - w II etapie uzyskano szybkość korozji testowych płytek Steel Shimstock na poziomie $0,0272 \mathrm{~mm} / \mathrm{rok}$, a stopień ochrony przed korozją kształtował się na poziomie $98,6 \%$. Po I etapie badania w przypadku inhibitora Pachem-CWR-1021 zaobserwowano wyraźny całkowity rozdział ropy naftowej od wody w krótkim odstępie czasu. W przypadku inhibitora komercyjnego B uznanej firmy szybkość korozji testowych płytek Steel Shimstock wynosiła $0,0499 \mathrm{~mm} /$ rok, a stopień ochrony przed korozją kształtował się na poziomie $97,4 \%$. Po I etapie badania stwierdzono jednak niepełny rozdział ropy naftowej od wody złożowej, a ilość ropy naftowej zwiększyła się z powodu wchłonięcia 
przez nią wody złożowej, co wpłynęło niekorzystnie na lepkość ropy oraz znacznie zwiększyło jej działanie korozyjne z uwagi na silny wzrost ilości chlorków w ropie.

Przeprowadzono również badania grubości warstwy ochronnej utworzonej przez inhibitor korozji do dozowania okresowego Pachem-CWR-1021 - według metody INiG - PIB. Stwierdzono, że wytworzona grubość warstwy wynosi 21,70 mikrometra. W przypadku inhibitora komercyjnego B kształtuje się ona na poziomie 10,20 mikrometra.

Podsumowując, badania wykazały, że inhibitor korozji do dozowania okresowego Pachem-CWR-1021, przeznaczony do ochrony czasowej przed korozją stalowych powierzchni rur wydobywczych w odwiertach naftowych, żerdziowych tłokowych pomp wgłębnych i ropociągów, tworzy na metalowych powierzchniach trwałą powłokę ochronną, która jest wyjątkowo odporna na spływanie pod wpływem działania ropy naftowej i wody złożowej oraz działanie temperatury do $65^{\circ} \mathrm{C}$. Badania wykazały, że inhibitor korozji Pachem-CWR-1021 wykazuje wysoką zdolność do wypierania wody i przeciwdziałania tworzeniu się emulsji ropy naftowej z wodą złożową oraz charakteryzuje się wysokimi właściwościami przeciwkorozyjnymi, chroniącymi powierzchnie metali przed korozją równomierną i wżerową wywołaną działaniem chlorków, ditlenku węgla i siarkowodoru. Dodatkową korzystną cechą tego inhibitora jest jego niska temperatura płynięcia.

\section{Inhibitor korozji Pachem-CR-1012 do ochrony instalacji destylacji rurowo-wieżowej DRW}

Przeprowadzono dynamiczne badania korozyjne z udziałem inhibitora korozji Pachem-CR-1012 do ochrony instalacji destylacji rurowo-wieżowej DRW, według NACE 1D182, z udziałem benzyny surowej i kondensatu wodnego pobranych $\mathrm{z}$ rafinerii A, zmieszanych w stosunku 50:50\% $(v / v)$, w obecności $\mathrm{CO}_{2}$, w temperaturze $65^{\circ} \mathrm{C}$, w czasie 72 godzin, przy dozowaniu $10 \mathrm{mg}$ na litr benzyny. Badania wykazały, że szybkość korozji testowych płytek Steel Shimstock kształtowała się na poziomie $0,11 \mathrm{~mm} /$ rok, a stopień ochrony przed korozją wynosił $96,0 \%$. Po badaniu zarówno benzyna surowa, jak i woda kondensatowa były przeźroczystymi cieczami, a ich rozdział nastąpił w krótkim czasie. W przypadku inhibitora komercyjnego $\mathrm{C}$ uznanej firmy szybkość korozji testowych płytek Steel Shimstock wynosiła $1,01 \mathrm{~mm} / \mathrm{rok}$, a stopień ochrony przed korozją kształtował się na poziomie $59,6 \%$. Po badaniu benzyna surowa była przeźroczystą cieczą, natomiast woda była lekko mętna - co świadczyło o zanieczyszczeniu węglowodorami, docelowo niekorzystnego dla środowiska naturalnego - i zawierała dużo osadów rdzawych - co świadczyło o zachodzących procesach korozyjnych.

Przeprowadzono również statyczne badanie korozyjne $\mathrm{z}$ udziałem inhibitora korozji Pachem-CR-1012 według PN-H-04601 i PN-H-04610, które wykonano dla benzyny surowej i wody kondensatowej pobranych z rafinerii A, zmieszanych w stosunku $80: 20 \%(v / v)$, w temperaturze $20^{\circ} \mathrm{C}$, w czasie 96 godzin, przy dozowaniu $15 \mathrm{mg} /$ litr benzyny. Badania wykazały, że w przypadku inhibitora korozji Pachem-CR-1012 szybkość korozji testowych płytek ze stali ST3S wynosiła $0,003 \mathrm{~mm} / \mathrm{rok}$, a stopień ochrony przed korozją kształtował się na poziomie $99,8 \%$. Po badaniu zarówno benzyna surowa, jak i woda kondensatowa były przeźroczystymi cieczami. Badania wykazały, że w przypadku inhibitora komercyjnego C uznanej firmy szybkość korozji testowych płytek ze stali ST3S wynosiła $0,71 \mathrm{~mm} / \mathrm{rok}$, a stopień ochrony przed korozją kształtował się na poziomie $63,6 \%$. Po badaniu benzyna surowa była lekko mętna, co świadczyło o zanieczyszczeniu jej wodą, natomiast woda również była lekko mętna, co świadczyło o zanieczyszczeniu jej węglowodorami, niekorzystnym dla środowiska naturalnego.

Przeprowadzono również badanie skłonności do emulgowania z udziałem inhibitora korozji Pachem-CR-1012 według ASTM G 170-06. Badanie wykonano dla benzyny surowej i wody kondensatowej pobranych $\mathrm{z}$ rafinerii A, zmieszanych w stosunku $80: 20 \%(v / v)$, w temperaturze $20^{\circ} \mathrm{C}$, przy dozowaniu $20 \mathrm{mg} /$ litr benzyny surowej. Badania wykazały, że w przypadku inhibitora korozji Pachem-CR-1012 po badaniu zarówno benzyna surowa, jak i woda kondensatowa były przeźroczystymi cieczami. W przypadku inhibitora komercyjnego C po badaniu benzyna surowa była lekko mętna, co świadczyło o zanieczyszczeniu jej wodą, natomiast woda również była lekko mętna, w postaci mikroemulsji, co świadczyło o znacznym zanieczyszczeniu jej węglowodorami.

Wyniki badań potwierdzają znakomite właściwości funkcjonalne inhibitora korozji Pachem-CR-1012 do ochrony instalacji destylacji rurowo-wieżowej DRW i możliwość jego przemysłowego zastosowania z uzyskaniem wysokich efektów w zakresie ochrony przed korozją instalacji DRW już przy niskim dozowaniu $10 \mathrm{mg} /$ litr benzyny, jak również z uzyskaniem czystych faz: czystej, niezawodnionej, pozbawionej produktów korozji benzyny surowej oraz czystej, pozbawionej węglowodorów i produktów korozji wody kondensacyjnej.

Artykuł powstał na podstawie projektu pt.: Innowacyjne środki chemiczne z udziałem zmodyfikowanej imidazoliny dla przemystu rafineryjnego, wydobywczego ropy naftowej, hutniczego i maszynowego - projekt dofinansowany ze środków NCBiR w ramach Programu Badań Stosowanych - Ścieżka A; umowa nr PBS/3/A1/15/2015.

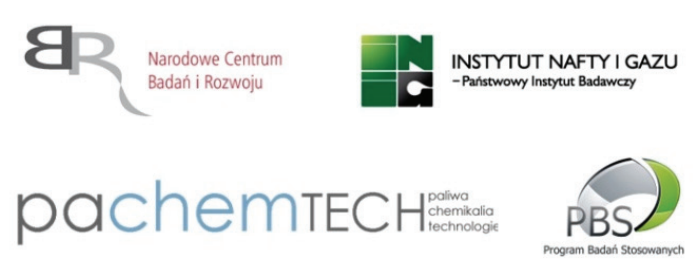




\section{Literatura}

Abd El-Lateef H.M., Abbasov V.M., Aliyeva L.I., Ismayilov T.A., 2012. Corrosion Protection of Steel Pipelines Against $\mathrm{CO}_{2}$ Corrosion-A Review. Chemistry Journal, 2(2): 52-63.

Arora A., Pandey S.K., 2012. Review on Materials for Corrosion Prevention in Oil Industry. Society of Petroleum Engineers. DOI: 10.2118/155211-MS.

Baszkiewicz J., Kamiński M., 2006. Korozja materiałów. Warszawa: OWPW, 9-13, 152-153.

Chen H.J., Jepson W.P., Hong T., 2000. High temperature corrosion inhibition performance of imidazoline and amide. International conference CORROSION. Paper No. NACE-00035. NACE International.

Fang C., 2001. Batch-inhibitor treatment size, shut-in time determined. Oil and Gas Journal, 99(15): 45-49.

Fink J., 2003. Oil field chemicals. Elsevier Science, 82-102.

Fink J., 2011. Petroleum engineer's guide to oil field chemicals and fluids. Elsevier Inc., 217-252.

Gaździk B., 2016. Procesy korozyjne w rafineriach i zapobieganie ich skutkom poprzez stosowanie inhibitorów korozji. Nafta-Gaz, 3: 198-206. DOI: 10.18668/NG.2016.03.07.

Groysman A., 2016. The Role of Corrosion Management in Prevention of Corrosion Failures. International conference CORROSION. Paper No. NACE-2016-7252. NACE International.

Jewulski J., 2007. Metody intensyfikacji wydobycia płynów złożowych. Kraków: Wydawnictwa AGH, 15-26.

Jewulski J., Wojnarowski P., 2007. Wybrane zagadnienia doskonalenia technologii wtórnych metod eksploatacji złóż ropy naftowej. Wiertnictwo, Nafta, Gaz, 24(2): 769-776.

Kuznetsov Yu.I., Vagapov R.K., 2000. On Steel Protection with Volatile Corrosion Inhibitors in $\mathrm{H}_{2} \mathrm{~S}$-Containing Media. Protection of Metals, 36(5): 474-478. DOI: 10.1007/BF02764095.

Manning F.S., Thompson R.E., 1995. Oilfield processing. Volume 2: Crude Oil, PennWell Corporation, 61-77, 269-291.

Menendez C.M., Bojes J.M., Lerbscher J., 2011. Batch Corrosion Inhibitor Film Thickness Measurements Using Optical Profiler, Corrosion. The Journal of Science and Engineering, 67(3): 1-12. DOI: 10.5006/1.3560117.

Moiseeva L.S., Kuznetsov Yu.I., 1997. Inhibition of carbon-dioxide corrosion of equipment of the petroleum and gas industry. Chemical and Petroleum Engineering, 33(1): 81-87. DOI: 10.1007/ BF02416791.

Moiseeva L.S., Yupashevskii V.E., Kamenshchikov F.A., Pushina O.I., Grigor'eva T.M., Sadov A.M., 1998. Effectiveness of corrosion inhibitors used in oil and gas fields. Chemical and Petroleum Engineering, 34(7): 482-486. DOI: 10.1007/BF02418894.

Osokogwu U., Oghenekaro E., 2012. Evaluation of corrosion inhibitors effectiveness in oilfield production operations. International Journal of Scientific and Technology Research, 1(4): 19-23.

Papavinasam S., 2000. Evaluation and Selection of Corrosion Inhibitors. [W:] Winston Revie R. (ed.): Uhlig's Corrosion Handbook. Second Edition (s. 1169-1178). John Wiley \& Sons, Inc.

Pawłowska B., Olszewska J., 2006. Problemy korozji w rafinerii. [W:] Surygała J. (red.): Ropa naftowa: właściwości, przetwarzanie, produkty (s. 540-560). Warszawa: WNT.

Popoola L.T., Grema A.S., Latinwo G.K., Gutti B., Balogun A.S., 2013. Corrosion problems oil and gas production and its mitigation. International Journal of Industrial Chemistry, 4(1): 1-15. DOI: $10.1186 / 2228-5547-4-35$.

Reiss Ł., Toporowski R., 2000a. Badania skuteczności inhibitorów korozji w roztworach solnych. Konferencja Naukowo-Techniczna Geopetrol 2000, Zakopane, 690-695.

Reiss Ł., Toporowski R., 2000b. Dobór organicznych krajowych inhibitorów korozji do płynów nadpakerowych. Międzynarodowa Konferencja Naukowo-Techniczna AGH, Kraków, 93-101.

Reiss Ł., Toporowski R., 2000c. Korozja rur wydobywczych i uzbrojenia wgłębnego odwiertów gazowych. Ochrona przed Korozją, 1: $6-8$.

Sintoorahat P., Wairatpanich A., Chimam S., Mongkholkhajornsilp D., Kang C., 2008. Performance of corrosion inhibitors at high $\mathrm{CO}_{2}$ pressures. ASME. 7th International Pipeline Conference, Volume 2, 227-232. DOI: 10.1115/IPC2008-64114.

Stachowicz A., 2009. Monitoring korozji przez pomiary stężenia jonów żelaza w płynach produkcyjnych odwiertów. Nafta-Gaz, 9: 978-981.

Stachowicz A., 2010. Inhibitorowa ochrona antykorozyjna dla urządzeń eksploatacyjnych i przesyłowych kopalni ropy naftowej i gazu ziemnego. Nafta-Gaz, 3: 197-202.

Stachowicz A., 2013. Korozja rur w odwiertach oraz dobór ochrony inhibitowanej w płynach nadpakerowych. Nafta-Gaz, 7: 525-531.

Tishkevich L.F., Vartapetov A.S., Kamlyk A.S., Filippov N.G., Frolov K.I., Miklyasheva I.V., 1996. Tests of Dodigen 481 Inhibitor in Corrosive Media at the Perm' Petroleum Refinery. Chemistry and Technology of Fuels and Oils, 32(1): 26-27. DOI: 10.1007/ BF00729854.

Wang H., Shi H., Jepson W.P., Hong T., Kang C., 2001. Characterization of Inhibitor and Corrosion Product Film Using Electrochemical Impedance Spectroscopy (EIS). International Conferences CORROSION. Paper No. NACE-01023. NACE International.

Wojnar K., 1997. Wiertnictwo - technika i technologia. Kraków: Wydawnictwa AGH, 555-598.

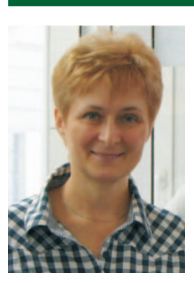

Mgr inż. Barbara GAŹDZIK

Starszy specjalista badawczo-techniczny w Zakładzie

Olejów i Środków Smarowych i Asfaltów

Instytut Nafty i Gazu - Państwowy Instytut Badawczy ul. Lubicz $25 \mathrm{~A}$

31-503 Kraków

E-mail: barbara.gazdzik@inig.pl

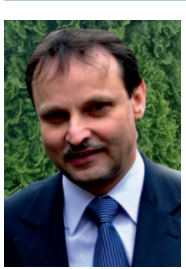

Dr inż. Roman KEMPIŃSKI

Dyrektor Naczelny

Pachemtech Sp. z o.o.

ul. Kobiałka $7 \mathrm{a}$

09-411 Płock

E-mail: Roman.Kempinski@pachemtech.eu

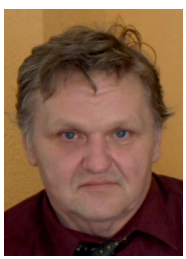

Mgr inż. Andrzej GAŹDZIK

Specjalista utrzymania ruchu

ArcelorMittal Poland S.A.

Koksownia Kraków

ul. Ujastek 1

30-969 Kraków

E-mail:ag28@wp.pl

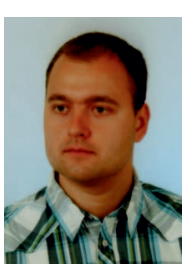

Mgr inż. Kamil POMYKAŁA

Specjalista inżynieryjno-techniczny w Zakładzie

Olejów, Środków Smarowych i Asfaltów

Instytut Nafty i Gazu - Państwowy Instytut Badawczy

ul. Lubicz 25 A

31-503 Kraków

E-mail:kamil.pomykala@inig.pl 